TEXT Vol 19 Special Issue No 30 (October 2015) Creative Writing as Research IV

\title{
Contents Part 1
}

- Eugen Bacon, We were young page 2

- Craig Batty, The (im)perfect screenplay: a parody of craft and industry page 8

- Denise Beckton, All she could see page 26

- Leonie Brialey, So Much Tongue page 29

- Donna Lee Brien, Women, birth, life and death: from the fictionalised diary of Mary Dean [extract] page 39

- Barbara Brooks, Mutitjulu diary: notes from February/March 1996 page 46

- Marion May Campbell, Snap page 52

- Shady Cosgrove, Dumpster diving: a family excursion page 57

- Moya Costello, pressed specimens page 65

- Enza Gandolfo, City ghosts page 70

- Thomas Hamlyn-Harris, Leonard's gambit page 77

- Ashley Haywood, Harlequin Blue; or, A place like Paris and a new brain map page 83

- Nigel Krauth, By the fingernails page 88 


\section{Swinburne University of Technology}

\section{Eugen Bacon}

\section{We were young}

Biographical note:

Eugen Bacon studied at Maritime Campus, Greenwich University, less than two minutes' walk from The Royal Observatory of the Greenwich Meridian. She is now a $\mathrm{PhD}$ candidate by artefact and exegesis at Swinburne University of Technology. Her short story 'A puzzle piece' was shortlisted in the Lightship Publishing (UK) international short story prize 2013 and is published in Lightship Anthology 3. Eugen's creative work 'Being Marcus' is published in New Writing, The International Journal for the Practice and Theory of Creative Writing.

Keywords:

Creative writing - short story narrative - first person plural - multiple narrator 
We waved to Dora in her ladybird dress full of sapphire ribbons. She waved back, a tangle of African lilies from Lake Park bobbing in her combed-out hair. A thousand brushes, $\mathrm{O}$ always said as he tenderly drew out each strand with the vented radial brush from her princess dresser.

Mum smiled briefly at $\mathrm{O}$, looked away swiftly and a frown replaced the smile as her sedan reversed out the driveway. There was no hint of softness on her face from just before, at the door, when she brushed O's lips with hers, when she clung to him for no greater than a moment. He stood tall at the doorway, head almost touching the dome, and watched as we pulled into the road.

Mum stayed silent down the freeway, even as we nagged: Are we there yet? Are we, are we? Normally she'd say, Not yet, mate, or What's going on? This time she didn't notice. Her grip was taut on the steering, her stare ardent down the road as if fretful the lanes might melt in the shimmering sun of the Southern hemisphere. Jesus, she cursed a Subaru Brumby, or the woman in it, or the dog in it that was the ugliest we'd ever seen - it looked like it wanted to sneeze - when the Brumby swerved into our lane but drove on way too leisurely. Ugly Dog barked and nearly gnawed the window as Mum took the car off cruise and we overtook. She turned Nova FM's countdown to full blast, bobbed her head to Uptown Funk, then Hozier when he sang Take me to Church, but her voice was wet when she asked if we'd like McDonald's, and we said yes.

We got Maccas from the drive-thru - a Chicken McBites meal deal and a Mighty Angus meal deal, one with zesty Portuguese sauce, the other with whipped butter, both with large fries and a chocolate frappe upsize. Mum was clearly grumpy because she snapped, Keep it down, will you? in the car. We stopped pulling at each other and took from her our dinner boxes as the attendant with cat ears and a ruby Roland nose handed them over. Before we even asked, Mum said we could eat in the car. Soon as we got out, she spat on a face tissue and wiped grease off our faces, oh, didn't we thrash! Before we stepped into the living room, Mum turned squarely to face us. She wore a brave face like she was about to take a needle, a flu jab or something, and said, What happened with $\mathrm{O}$, it wasn't your fault.

That summer at O's wasn't fun. He was self-medicating for his migraines, doubling doses of codeine, and his mood was getting more and more grotty. His voice still held a silk note for Dora but for us it was always the growl, a bigger growl. He barked when we set up accounts on the PlayStation - although it worked better, later he agreed, and Dora could still play all her favourite games. After he bellowed at us in the car, then turned the car round so we went back to his house instead of driving to Lake Park as he promised, Mum also saw he wasn't fun. She jumped out the car soon as it stopped, marched fuming into the house, and - before we could do the same - O said, Children, stay in the car.

Who needed to get out to hear them tearing at each other? Horrible words from the sound of them, but what was actually said could have been worse.

When I say anything to them, you think I'm a bully! 
Did I say anything when you jumped at them in the car? Sure, I was surprised when you turned round -

I'd had enough!

And I could see why their bobbing might annoy you -

And you did nothing!

Because you did something.

I had to!

What's done is done. So what do you want from me now? Tell me, what? Already you've roared at them, and turned back the car -

I wanted you to do something!

But you'd already done something!

A whole 400 meters, I waited! And now you storm out of the car - clearly you're upset I did something.

The only reason I stormed was because I was still mad at you for spoonfeeding Dora. Christ, O. She's not that little.

Mad? Why would you even say that? She's never eaten so well!

Why don't you just go ahead and put a nappy on her? A nappy!

Did you see how she ate all the peas?

Did you realise how it's called double standards? Feed your little princess with a golden spoon! But my ones - well they are not your biological kids - but they can never do anything right, can they?

You can't control them -

Put a nappy on her!

She ate the whole lot!

We watched them stare at each other in astonishment, shattered by their rage at each other.

They buried the fight and slumbered together and Mum went for a run in the morning. At lunchtime she said, Kids? Cheese toasties?

But we've eaten, we said.

Eaten what?

Sausage rolls, said Dora.

Mum said to O, The kids say they've had sausage rolls.

For breakfast, he said.

How long since breakfast? 
You deal with it, he said. If they don't want to eat, they don't want to eat.

Mum warmed the leftover pie and sat with $\mathrm{O}$ at the table. She raised her lemonade and said, Salute! It sounded like how the Italians say it but nobody answered. So Mum feigned more cheer. At dinner, she said, let's indulge us voracious meat eaters would you like me to get some barbie from the butchers?

What I would like, said O through gritted teeth, is for you to take your kids and go.

We didn't leave straight away, perhaps because Mum packed all her stuff everything, even the champagne from the fridge - and O said, kinder, Are you going for good?

Yes, said Mum.

I wasn't escalating, said O. I just want to spend a few days with Dora. I don't get her much from her mother.

Mum didn't say, And who's too tight to pay the lawyers? Instead she said, We're struggling, don't you see? That was when she pressed her lips on O, put the car in reverse, smiled and waved briefly before she frowned, and we were gone.

That night she sat up, startled, from broken sleep. She said it was a bad dream, something about AirAsia 8501 and too much news. We wondered what she had seen in her sleep, if there were bodies flying into space, gale and altitude whipping off clothes, bodies bloated in water tombs.

We stroked Mum's hair with our fingers, not a brush, and told her we took everything from our room at O's. Even Gods of War, we said.

I'm glad you took everything, she said.

O's house was awkward, we said. Did you see how it was awkward, Mum?

She didn't tell us it wasn't O's house that was awkward but that it was us who had turned awkward in it because everything was by then compromised, complicated. She didn't say that all was lost, how could there be a future? How five gritted words, Take your kids and go, had put sand into whatever there was with O. She didn't tell us how the swallowing pain of loss was inside out, how - if only $\mathrm{O}$ knew - she was a simple phone call away from restitution ... But he never called.

The next day was forty degrees. Mum pressed the remote button and the air con coughed to life before it groaned and grunted all day. By the third nightfall, Mum had weakened and was reaching for the phone when she snatched back her fingers as if from a flame. For what? she said out loud. Indeed, for what? We also wondered because we didn't want her driving back to O's. But, you see, Mum understood what we didn't at the time, that sometimes love is not enough.

Next day, she slept until noon - an oddity for one always up at six. But she wasn't asleep, we knew. She lay with criss-crossed hands against her shoulders, arms that cuddled her head, as she stared at the silver on the door handle, at the white of the bedroom door, at a replay in her head of all the good memories (like how $\mathrm{O}$ drove barefoot all the way to the Boulevard lights), and too many bad ones (like how O got 
mad because Mum bought ultrasabres that lit up with sound effects, at 18 bucks apiece from the roadside stall in Ivanhoe).

I feel like fish, she said when she finally climbed out of bed. After a 20-minute shower, a blast of it, she got smoked salmon from Aldi. She ate it with two boiled eggs and stank the whole house, but for us it was spirals bolognaise without parmesan on top, just how we liked it.

On New Year's Eve we took blankets to Fed Square and joined throngs to face the sky, and Mum's eyes were shining, shining ... Fireworks squealed at us from the heavens and chased to the ground mouth open, but retched out a jazzy montage before they could reach us. Afterwards we were so tired but Mum said we were too big to carry and, soon as we got home, we slept the bottomless sleep of gods after war.

The next day was still blooming hot. So Mum gave us money to get paddle pops from the corner shop. We bounced off without wondering if she felt like we had when $\mathrm{O}$ sped off alone with his precious Dora in the back seat, off to Lake Park they went, after him and Mum had torn each other with horrible words, after he returned from his fight with Mum and kicked us out of his sedan. We forgot to ask Mum - how could we forget, but we did - if she wanted an icecream to cool the embers of her charred heart.

But we were young. 


\section{Research statement}

\section{Research background}

In trialling first person plural for short fiction, I have applied multiple 'I's as a viewpoint of more than one to demonstrate the flexibility of stories told by 'we' here used as a real multiplicity rather than as a collective voice showing distance (Nesbit 2014). 'We were young' is narrated by the compound child in a split family who experiences singular effects. I imagined the narrators as monozygotic (Fierro 2015a): twins, triplets, quadruplets, higher order multiples whose identical DNA afforded entwined lives, an inherent understanding of each other's emotional state (Fierro 2015b).

\section{Research contribution}

This text demonstrates the short story as removed from the sub-genres of tale, where it is not a parable or a fable, not a creation myth, not a novella, not a fairy tale, and not an art-tale. 'We were young' steps into another world, a real one, showcasing the robustness of the short story as an immediate and accessible window into contemporary life. It highlights the form's flexibility, which allows it to work in experimental form, where - in this story - the protagonists report collectively with little individualisation (Nesbit 2014), with both immediacy and retrospection.

\section{Research significance}

'We were young' is an immediate and accessible window into contemporary life, a brief narration of domesticity. The story has been accepted for publication in a reputable refereed journal.

\section{Works cited}

Fierro, Pamela P 2015a 'Identical twins', About Health, at http://multiples.about.com/od/funfacts/a/identicaltwins.htm (accessed 5 January 2015)

Fierro, Pamela P 2015b 'Twin telepathy', About Health, at http://multiples.about.com/od/funfacts/a/twintelepathy.htm (accessed 5 January 2015)

Nesbit, TaraShea 2014 'We can do a lot: The rise of first-person plural narration' The Guardian Books Blog 15 May, at http://www.theguardian.com/profile/tarashea-nesbit (accessed 6 January 2015) 


\title{
RMIT University
}

\author{
Craig Batty
}

\section{The (im)perfect screenplay: a parody of craft and industry}

\begin{abstract}
:
Drawing on the author's twelve years of teaching, researching and writing about screenwriting craft, this work draws attention to formulaic conventions and the industry in which they operate in the form of a parody of an episode of a hypothetical low-budget Australian soap opera. It is structured as a soap opera typically would be, with an episode containing parallel and tonally different storylines set in the context of a day, but deliberately exploits craft and convention to the extreme. In the vein of Victoria Wood's Acorn Antiques, a television sitcom that parodied 1980s British soap operas, The (Im)Perfect Screenplay: A Parody of Craft and Industry seeks more critically to reveal the hidden (to many) craft techniques of screenwriting by creating an explicit awareness of how they operate within a well-known genre and format. By doing so, the work offers simultaneously a perfect and an imperfect screenplay. It contributes to the field of screenwriting in the academy through the performative potential of the screenplay as a research artefact.
\end{abstract}

\section{Biographical Note:}

Craig Batty is Associate Professor of Screenwriting at RMIT University, where he is also Creative Practice Research Leader for the School of Media and Communication. $\mathrm{He}$ is a screenwriter, script consultant and script editor, with experiences in short film, feature film, television and online drama. He is author, co-author and editor of eight books, including Screenwriters and Screenwriting: Putting Practice into Context (2014) and Writing for the Screen: Creative and Critical Approaches (2008).

Keywords:

Creative writing - screenwriting craft - screenwriting industry - parody screenwriting as research 


\section{The (Im)Perfect Screenplay: A Parody of Craft and Industry}

1. EXT. PARK - MORNING

ELLIE (late 20s, intellectual) and RICK (late 20s, bluecollar worker) walk through an empty but beautiful park.

Ellie seems radiant, breathing in the air. Rick seems bored.

A long beat before anything is said.

\section{ELLIE}

Sometimes we really don't know what we have.

Rick, looking at his phone, mumbles. Ellie pauses and takes in the surroundings with wide, expectant eyes.

\section{ELLIE}

It's like I'm seeing it for the first time.

\section{RICK}

You drag us here most weeks, babe.

Ellie gives a resigned smile, like she knows this only too well. She looks at Rick, who's smirking at a text message.

Long pause before they continue to walk.

\section{ELLIE}

We come, but ... it's like, we're here but we're not here.

RICK

(looks up)

Are you on something?

They approach a bench - it's old and crumbling, but still standing proud.

Ellie nods towards it - but Rick is slow on the uptake. Ellie sighs, and nods again - this time more obviously. 
Rick waits for an answer but there isn't one. Instead, Ellie gives him a smile that says, 'Yes, please, it's important that we do this.'

Rick takes the hint and sits. He looks at Ellie, suspicious.

\section{RICK}

Why didn't you just say?

\section{INT. OFFICE, CORRIDOR - MORNING}

KYM (early 20s, sexy beyond her years) waits for the lift. She uses the reflection of the doors to check her hair.

As the lift arrives and the doors open, she's not exactly pleased to see BEN (late 20s, a real stud - and he knows it) inside. She glares at him and then steps in, turning around dramatically so she doesn't have to look at him.

\section{INT. OFFICE, LIFT - MORNING}

Ben eyes up Kym's figure as the doors close.

As the lift goes down, Ben keeps looking. He knows she wants to turn around - she knows it too - but nothing.

Suddenly, the lift comes to an abrupt stop. The main lights go off and the emergency light comes on.

KYM

You have GOT to be kidding me.

Ben smirks and loosens his tie.

\section{EXT. GARDEN - MORNING}

A spade slams into the ground and pulls away a lump of earth. This is the work of ALAN (late 60s), a man with more time on his hands than he cares to think about.

Alan slams the spade in again, determination in his eyes.

His wife of forty years, SYLVIE (late 60s), comes out in a floral apron. She has a mug of steaming hot tea for Alan. 


\author{
ALAN \\ You're a darl. \\ SYLVIE \\ I know.
}

Alan takes the tea from Sylvie and takes a sip, savouring the taste. His eyes close with pleasure.

$$
\begin{gathered}
\text { SYLVIE } \\
\text { How's it all going? }
\end{gathered}
$$

ALAN

A lot of turning, but it's starting to look good.

SYLVIE

Smells good, too.

\title{
ALAN
}

The smell of life.

They both sigh at the same time - and gaze at the garden for a moment.

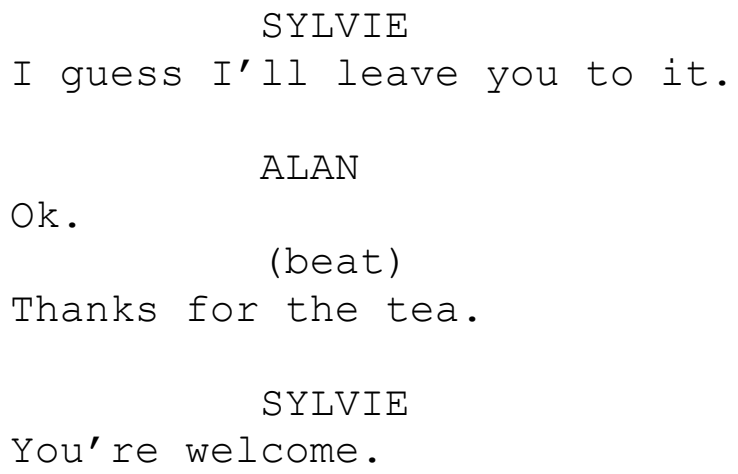


You're not here. You don't exist.

BEN

Ouch!

Kym finally turns around to look at him. Taking in his beauty, she falters for a second. But then:

\section{KYM}

You lost the right to speak to me the day you decided YouTube was your new best friend.

\section{BEN}

You always said you wanted to be a star.

Ben knows he's right, and Kim knows he's right, but she's too angry to talk. She tosses her head, turns the other way and continues to press the call button.

6. EXT. PARK - MORNING

Ellie faces Rick, but is looking beyond him. Rick's texting .

\section{ELLIE}

It's like ... (beat)

What was your favourite toy, when you were a child?

Rick wasn't expecting this question. He seems bamboozled.

\section{ELLTE}

Don't get me wrong, I'm not saying I don't like to play now and then. It's just ...

(beat)

I remember my doll. Mille. I thought it sounded like Ellie.

Ellie chuckles. So does Rick - but at the text message he's just received.

\section{ELLIE}

She was my world. My friend. My family. I'd do anything for her. For a time. But then ... you become 


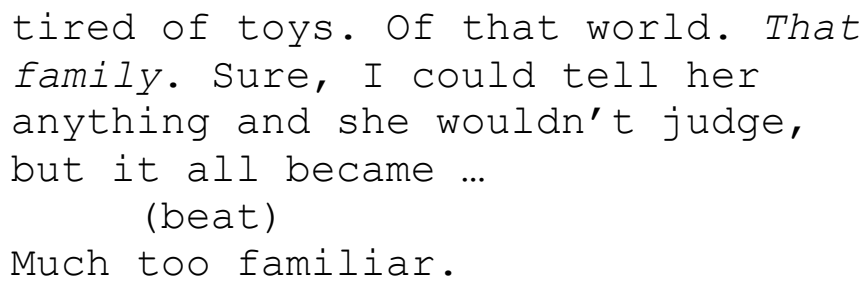

Rick gives her a curious look.

ELLIE

It was hard, and I knew I'd miss

all the things we did together.

(giggles)

Changing the dress, combing her

Hair ... telling her my secrets. (beat)

It was time to put her back in her

box. And tape down the lid.

Rick kind of twigs. He shuffles awkwardly and looks at Ellie.

\section{RICK}

Are you breaking up with me?

Ellie at last looks into Rick's eyes - but before she can say anything, a phone call interrupts the silence.

7. INT. PUB - AFTERNOON

MORRIS (60s, anorak wearing busy-body) is talking with CLIVE (50s, still 'got it') at the bar.

MORRIS

I'm telling you, clear as day, written down in black and white.

Barmaid IRENE (40s, dressed like she's in her 20s) passes over two beers.

IRENE

There you go, fellas. 


\section{CLIVE \\ And one for yourself, darl.}

Clive passes over a $\$ 20$ note.

IRENE

Ooh, I think I'll have to save

myself for later ...

She gives Clive a dirty wink and tootles off, wafting herself with the $\$ 20$ note. Clive sips his beer and licks his lips.

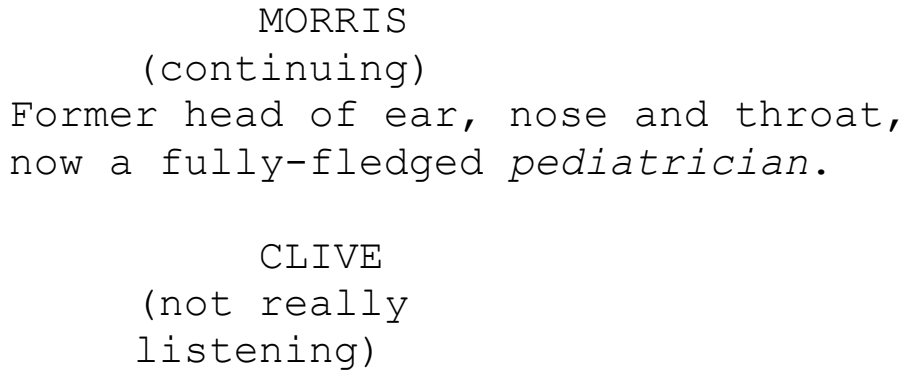


Morris almost chokes on his beer.

CLIVE

You've got to give it to the guy -

he's kept his focus and worked hard

to get what he wants.

(beat)

We could all learn from that.

Clive raises his beer towards Irene.

Morris, totally out of his depth here, slowly edges away.

8. EXT. GARDEN - AFTERNOON

Alan is still digging. The hole doesn't seem to have changed much since the last time.

Sylvie comes out with another mug of tea, this time wearing a different floral apron.

\section{ALAN}

My heroine!

\section{SYLVIE}

Oh Alan!

She passes him the tea. He takes a sip as Sylvie looks at the garden.

ALAN

It's coming on well.

SYLVIE

Looks like it.

They both sigh at the same time.

\section{SYLVIE}

I'll leave you to it then.

ALAN

Thanks, darl.

SYLVIE

Play your cards right and I'll bring

you a tea later.

ALAN

What would I do without you, hey? 
Sylvie smiles as she heads back to the house. She glances back before she steps inside.

Alan continues to dig.

9. INT. OFFICE, LIFT - AFTERNOON

Kym now looks tired - she's standing but shuffling about a lot. Ben's keeping his cool by sitting on the floor, legs wide apart.

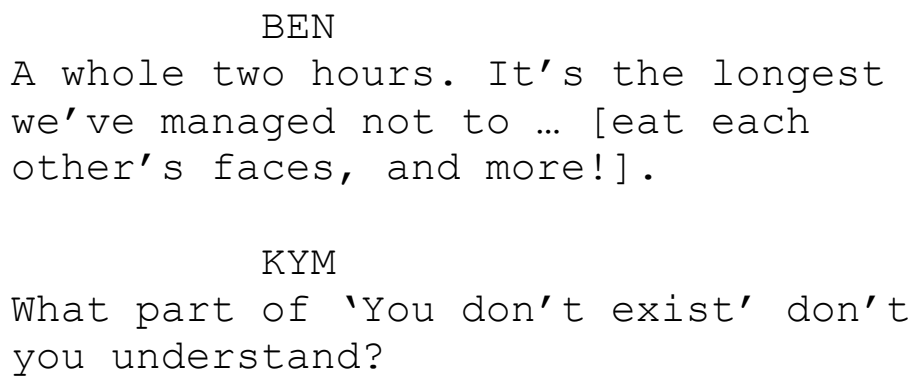

Ben thinks for a second.

\section{BEN}

\section{All of it?}

He takes out some chewing gum and smugly puts it in his mouth. He offers one to Kym. She wants to refuse but knows deep down that it'll help her to calm down.

She lets out a shrill of defeat as she takes one from him.

\section{BEN}

That's my girl.

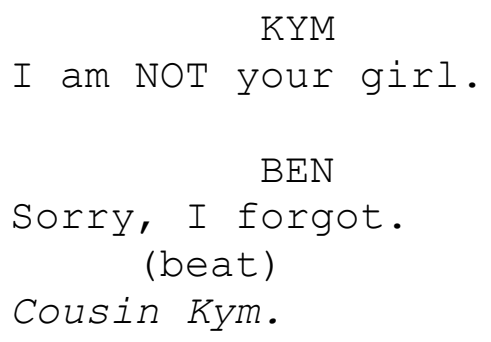

This is enough to really piss her off. She chews really hard then spits her gum at him. It lands on and sticks to his tie. 
Ben looks up at Kym - there's definitely a sexual charge.

10. INT. PUB - AFTERNOON

A group of people sit in a booth, laughing hysterically. DREW (30s, always on edge) walks into the middle of it all.

MARY (60s, battle-axe) clearly seems to be in charge.

$$
\begin{gathered}
\text { MARY } \\
\text { You just wouldn't credit it! }
\end{gathered}
$$

DREW

What's going on?

ROBERTA (40s, wet as water) pipes up.

ROBERTA

And when she said that she wouldn't

... and then he said that he would ...

ANGELA (50s, village idiot) has an unfortunate verbal quirk.

\section{ANGELA}

Spam!

DREW is trying to make sense of it all.

MARY

And they both did it anyway!

Everyone laughs again, this time even more knowingly.

DREW

Who are we walking about?

MARY

You really had to be there.

Drew smiles, but clearly feels left out.

ANGELA

Knife and fork!

11. INT. OFFICE, LIFT - AFTERNOON 
Kym has her skirt hitched up and Ben is - well pleasuring them both. The lift shakes slightly.

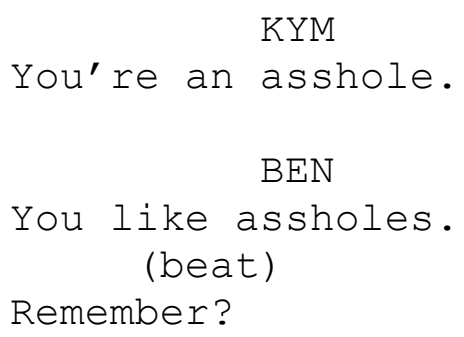

Kym tries to push him away but he only holds her closer. And she likes it.

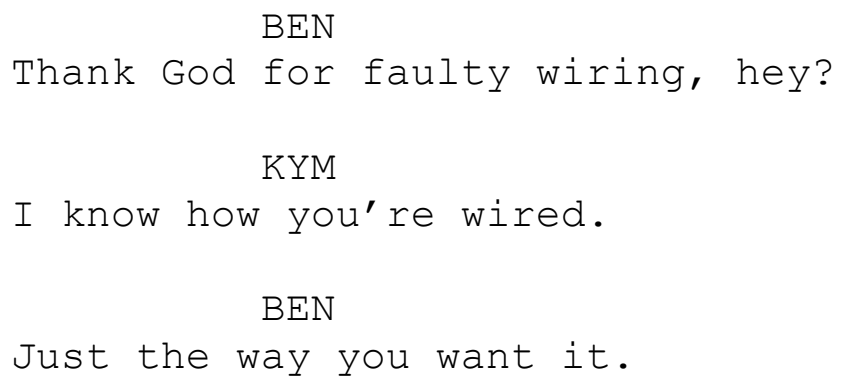

Kym takes hold of Ben's face and makes him look into her eyes.

$$
\begin{gathered}
\text { KYM } \\
\text { What's your instinct now? }
\end{gathered}
$$

The lift is moving - but neither of them realises.

BEN

$$
\text { To shut you up. And ... [to carry on }
$$




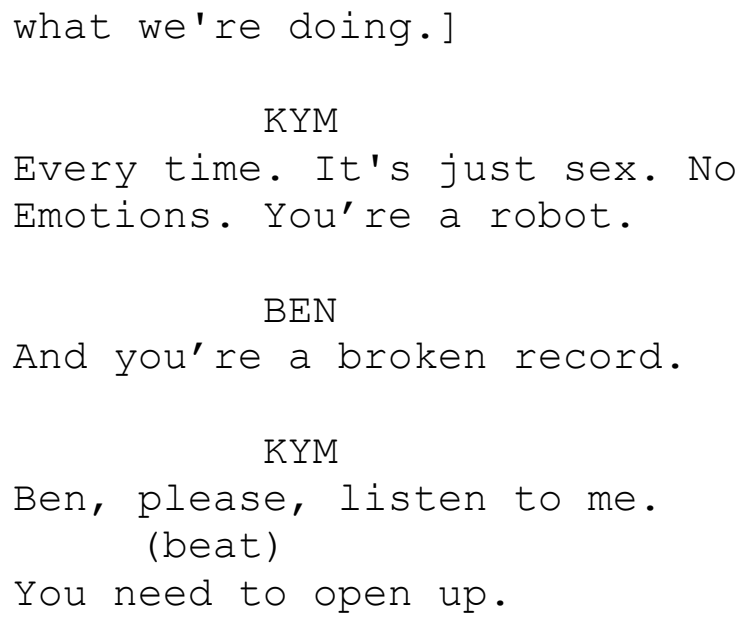

This phrase delights Ben - but before they can do or say any more, the lift doors also open up.

Standing there is a crowd of people, including their boss GEMMA (40s, hard-nosed) and a few amused FIREFIGHTERS.

Kym is mortified. She pulls herself away from a casual Ben .

GEMMA

What the hell is this?!

Kym almost cries. Ben zips himself up.

\section{$\mathrm{BEN}$}

Team building?

\section{INT. PUB - AFTERNOON}

The people in the booth are still laughing. Drew now looks impatient - if not a little paranoid.

MARY

And then when she said that about the sock drawer!

\section{ROBERTA}

I never did understand peep-toe sandals. Especially in the context of what she then told him her dad had done with the shoe buffer when they went on a long-haul family holiday in 1987.

More laughter as Irene comes over with a tray of drinks. 
IRENE

This round's on me, folks.

A communal cheer.

ANGELA

Money grabber!

Irene doles out the drinks - but there isn't one for Drew.

IRENE

Sorry, love, you must have arrived late.

DREW

Yes, I ... had to go see the doctor.

MARY

No more chiropody stories today,

Drew - you'll put me off my dry

roasted!

Everyone laughs - and this time also raise their glasses.

ANGELA

Costa del sol!

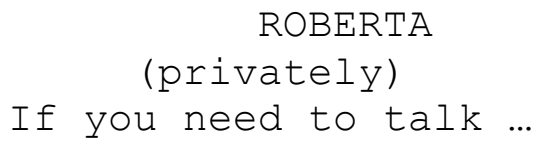

IRENE

Come on, Drew, what you having?

DREW

Is it free?

ANGELA

Down the hatch!

MARY

(re: Drew)

Listen to him, the cheapskate!

IRENE

That was for something else. When

you hadn't arrived. You really

had to be here.

Drew is embarrassed. Everyone looks at him, waiting. 
DREW

Lemon and lime bitters, please.

Irene nods and waltzes off. Roberta smiles

sympathetically.

MARY

(remote)

I bet he is, having to pay $\$ 4$.

ANGELA

(remote)

Myra Hindley!

\section{EXT. HOUSE, GARDEN - AFTERNOON}

Ellie follows Rick up the garden path. He's in a bit of a daze but she's displaying all the signs of someone who's lifted a great weight of their shoulders.

$$
\begin{aligned}
& \text { ELLIE } \\
& \text { It's not you, it's me. } \\
& \text { (beat) } \\
& \text { We can still be friends. }
\end{aligned}
$$

Ben takes out his key. He tries to open the door but struggles to get the key in the lock.

\section{ELLIE}

I love your family. I hope we can stay in touch.

Ben, still struggling, drops the key.

They both go to pick it up and not realising, knock heads.

They both go to say something, but can't. Awkward silence with lots of deep staring into eyes.

Ellie suddenly picks up the key.

\section{ELLIE}

You never did tell me your

favourite toy ...

As they both stand:

BEN

I never was one for favourites. 
Ellie opens the door and gestures for Ben to go in first. BEN

Dare I ask if there's any chance we might try again?

Ellie bites her lip. She displays a face full of emotions - bad and good.

\section{BEN}

I'll take that as a no then ...

He goes into the house. Ellie's body as well as her face is now displaying a range of emotions - good, bag and ugly.

\section{EXT. GARDEN - EARLY EVENING}

Alan still digs, but the hole is now not a hole - he's filling it back up.

Sylvie appears behind him with another mug of tea, wearing yet another floral apron.

He gives her a peck on the cheek as she passes him the mug .

Sylvie heads back to the house, but stops. She turns.

SYLVIE

It's starting to get dark.

ALAN

That it is.

Sylvie heads back into the house. Alan looks at the 'hole'.

16. INT. PUB - EARLY EVENING

Clive is in deep conversation with Irene. To one side, Morris is clearly gossiping about them to an INNOCENT BYSTANDER.

Over in the booth, Mary is packing up her things.

MARY

He'll be expecting his Thursday pie 
and mash.

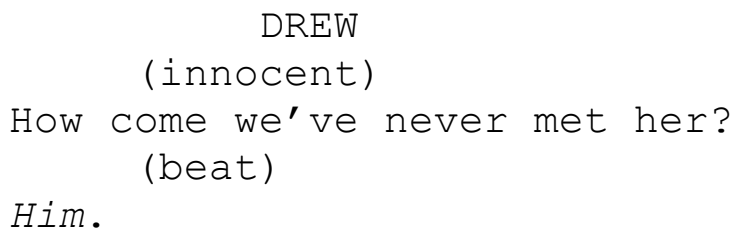

DREW

(innocent)

How come we've never met her?

(beat)

Him.

Awkward silence - this is clearly a topic nobody discusses.

Mary stops in her tracks. Angela looks at Drew. Roberta hides her face in her drink.

\section{DREW}

I mean ... we've known each other for years now and ... [I thought we might have met this mysterious partner at least once.]

MARY

Unlike some people in this pub, Drew, I'm not one to pry in other people's lives.

ANGELA

Chameleon!

Sensing the tension, people in the pub start to look over.

MARY

And the day I do is a black day for all of us.

ANGELA

Bushfire!

Drew is very uneasy - how can he diffuse the situation? ROBERTA

He didn't mean anything by it, Mary.

Over by the bar, Morris is soaking up the tension. He's managed to embroil Irene and Clive in the judgements.

DREW

If I had a ... partner, I'd want to show them off all the time. 
Roberta gives him a coy smile - is there subtext here?

Mary steps out of the booth and straightens her collar.

MARY

I'm not one to repeat myself, but

that, Drew, would be a black day

for all of us.

She holds her head high and strides out of the pub, passing a forlorn Rick who enters at the same time.

A moment of silence before people carry on with what they were doing.

In the booth:

DREW

Well that's set the cat amongst

the pigeons.

ROBERTA

Don't beat yourself up. She's

been in a funny mood all day.

Drew sighs. He looks over the bar and sees Morris looking over at him, knowingly.

$$
\text { Had to be there! }
$$

\title{
17. EXT. GARDEN - EARLY EVENING
}

Alan smoothes over the hole that he's now filled back in. He drops a lump of grass over the top of it and pats it down.

He stands back and looks at his work, pleased.

He heads to the house, puts the spade to one side and takes off his gardening shoes.

As he steps into the house:

\author{
ALAN \\ (remote) \\ Shall I put the kittle on, love? \\ END OF SCRIPT
}




\section{Research statement}

\section{Research background}

This work sits within the emerging field of screenwriting practice as research and, specifically, the screenplay text as both creative writing and research artefact. Its content draws on the author's 12 years of researching screenwriting to offer a metanarrative about how craft is deployed on the page for particular story effects. Responding to recent debates about the potential of screenwriting practice as research (Baker 2013, Baker et al. 2015), the screenplay performs the research through its form and content.

\section{Research contribution}

A parody of an episode within the soap opera genre, the work draws attention to industry craft techniques/conventions by explicitly performing them. It uses both 'perfect' and 'imperfect' modes of operation, creating a collision of 'good' and 'bad' screenwriting. Examples include: starting scenes as late as possible and 'too early'; drawing attention to backstory but denying its exposition to take place; and, contrasting high drama with no drama at all.

\section{Research significance}

An invited contribution to this special issue, the work adds knowledge to the discipline of screenwriting through its embodiment of research in the form of a screenplay. Significance can be found in how the work composes screenwriting research as well as the author's own reflexivity, in which he reflects on his research career, to use it as the subject of critical inquiry. The author's fourth such work to appear in an academic journal, it is still one of only a handful of published 'academic screenplays' internationally.

\section{Works cited}

Baker, D 2013 'Scriptwriting as creative writing research: a preface', TEXT, special issue 19, at http://www.textjournal.com.au/speciss/issue19/Baker_preface.pdf (accessed 12 May 2015)

Baker, D, C Batty, D Beattie and S Davis 2015 'Scriptwriting as a research practice: expanding the field', TEXT, special issue 29, at

http://www.textjournal.com.au/speciss/issue29/Baker_Batty_Beattie\&Davis.pdf (accessed 12 May 2015) 


\section{Denise Beckton}

\section{Central Queensland University}

\section{All she could see}

\section{Biographical note}

Denise Beckton, BA Ed (ECU), Grad Dip PH (Curtin), Grad Cert CI (CQU), has a background in public health and education and is currently a tutor in Creative Industries at Central Queensland University (Noosa campus) where she is a research higher degree candidate, writing a novel and a related dissertation. Beckton has attained multiple awards in the fields of education and public health including the national ACHPER Award for excellence in Health and Physical Education, The WA Healthways Award and a category finalist notation for the WA Premier's Award (Education). Her latest publication centers on teaching pedagogy in the Creative Industries field.

Keywords:

Creative Writing - short story - statistical analysis - grief 
Jayne tucked a curl of wayward hair behind Emily’s ear.

'Pop loved you, you know', she said.

'I know, I loved him too', said Emily, as she pulled her gaze from the casket at the front of the church to the letter that sat on her lap. She'd read it so often now that the paper was soft and no longer crinkled when unfolded.

Jayne gave her daughter a sideways squeeze.

'You can leave it on top of the coffin if you like - when you say your goodbyes'.

'Will they make sure he gets it?' asked Emily.

'Yes Em, they'll make sure it goes with him'.

Jayne looked over her shoulder to the rows of faces behind her. The genes were strong on Tony's side; she could pick his relations a mile away and saw glimpses of her husband's features scattered, here and there, throughout the pews - a square jaw in the third row, a set of rugby shoulders, impossibly big for the narrow church seats, and in Emily's wavy blond hair beside her.

She was surprised at the turnout and wondered how many, like her, had come to the funeral out of a sense of obligation. Tony's father had died the week before and she still didn't feel a thing; she couldn't find the proper way to feel. How could she? Sometimes it took her longer than that to find the bottom of the ironing basket. She would need more than a week to forgive him, and there was not enough time in the world to forget the things he'd done.

Tony stood next to his father's coffin and a line of people gathered behind him, ready to follow his lead. The microphone clicked as he turned it on and a piercing screech echoed through the vaulted church ceiling. Tony's voice was shaky. Jayne shifted in her seat - she'd never seen him like this before. He cleared his throat then launched into vivid memories of his dad as a loving father, the font of wise advice and the go-to man for belly laughs. It was a nice image but Jayne didn't buy it.

All that Jayne could see were drunken rants, overflowing ashtrays and the source of so many tears.

Friends who had cut all contact, years before, now reminisced about childhood pranks and camping trips. Burnt business partners rebranded dodgy deals as 'how-to' lessons of savvy investment. And she listened as, one by one, the old man's sins were washed away. She took Emily's letter and smoothed the creases against her legs. An unbroken string of x's and o's bordered the edges of the page. Jayne ran her open palm over the script.

I will miss you pop when you are in heaven.

I liked it when you put me on your shoulders.

Jayne closed her eyes and tried to find some of the love that Emily had for the man who called her princess. It helped, even if a loving Pop was all she could see. 


\section{Research statement}

\section{Research background}

Kessler notes that 'we think sometimes we're only drawn to the good, but we're actually drawn to the authentic ... people who are real more than those who hide their true selves under layers of artificial niceties' (2000). This story is an outcome of a research project that extends this discourse by exploring the underrepresentation of anger and guilt - emotional components identified by Kübler-Ross's 'Seven stages of grief' model (1969) - in relation to successful publications of short stories that identify grief as a theme.

\section{Research contribution}

This story is informed by a statistical analysis of a series of recent successful short story submissions about grief. Using this, together with qualitative analysis of fictional narratives (Spencer 2013), affirms a connection between the incidence of Kübler-Ross's stages of grief and a collection of short stories published on this theme.

\section{Research significance}

This story contributes to the current discourses around how those in Western culture express grief. The under-representation of anger and guilt in this regard, speaks to the concept of 'disenfranchised grief' as expressed by Hall, who recognises that 'societies have ... grieving rules' (2011) - and indicates the research potential for a wider representation of grief in short story narratives. This story has been accepted for publication in a high quality creative writing research journal.

\section{Works cited}

Hall, C 2011 'Beyond Kübler-Ross: recent developments in our understanding of grief and bereavement' InPsych, at https://www.psychology.org.au/publications/inpsych/2011/december/hall (accessed 14 September 2015)

Kessler, D and E Kübler-Ross 2000 Life lessons: two experts on death and dying teach us about the mysteries of life and living Scribner: New York

Kübler-Ross, E 1969 On death and dying Scribner: New York

Spencer, K 2013 'New modes of creative writing research' in (eds) J Kroll and G Harper Research methods in creative writing Palgrave Macmillan: Hampshire 


\section{University of Melbourne}

\section{Leonie Brialey}

\section{So Much Tongue}

Biographical note:

Leonie Brialey is a $\mathrm{PhD}$ candidate at the University of Melbourne.

Keywords:

Creative writing - comics - sincerity - mindfulness - mind-body 


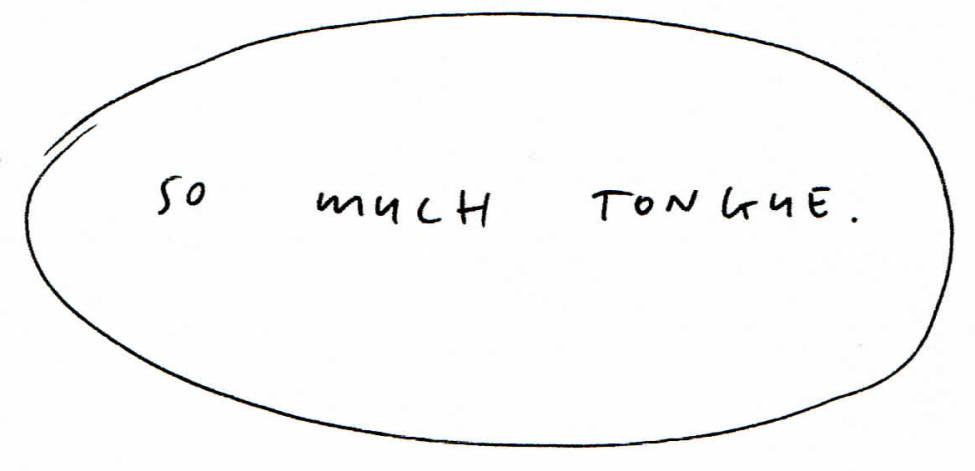


IN 2009 THIS WEIRD THING HAPPENED WHERE MY

TONGUE SWELLED MP:

EATING,
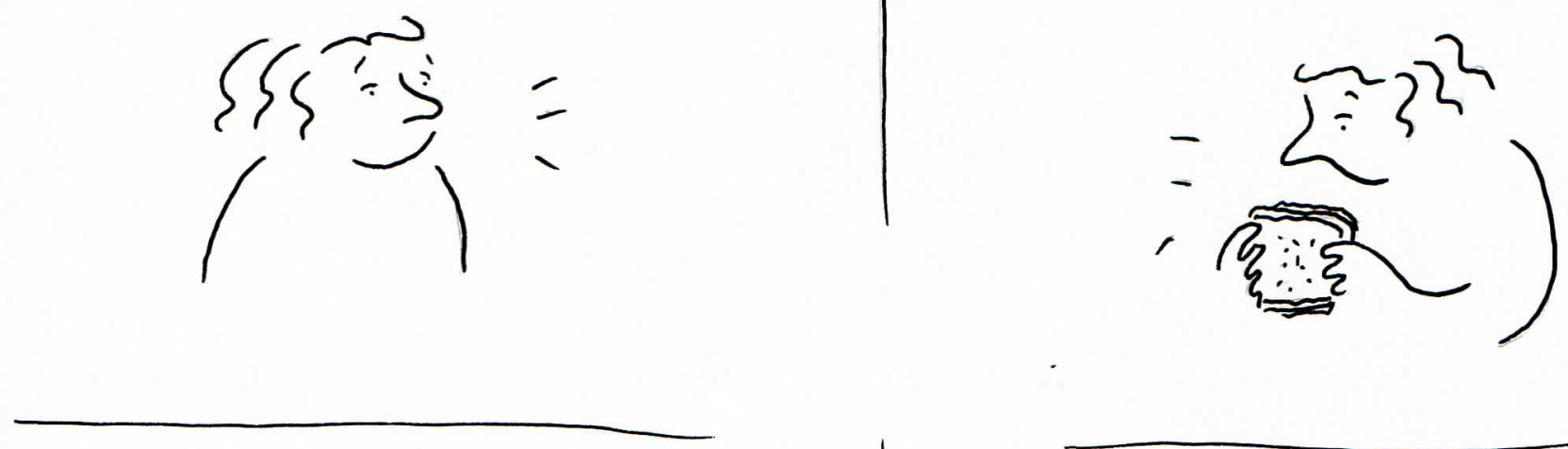

DRINKING,

TALKING,
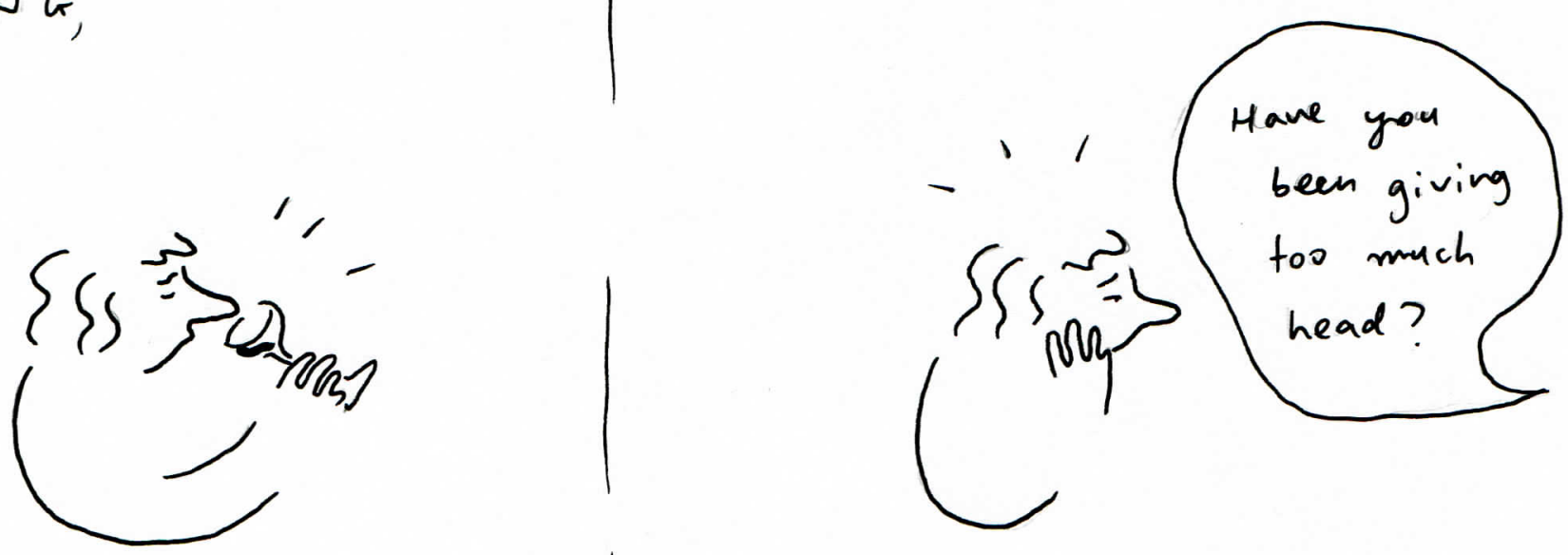

$k I S S I N G$,

All became very

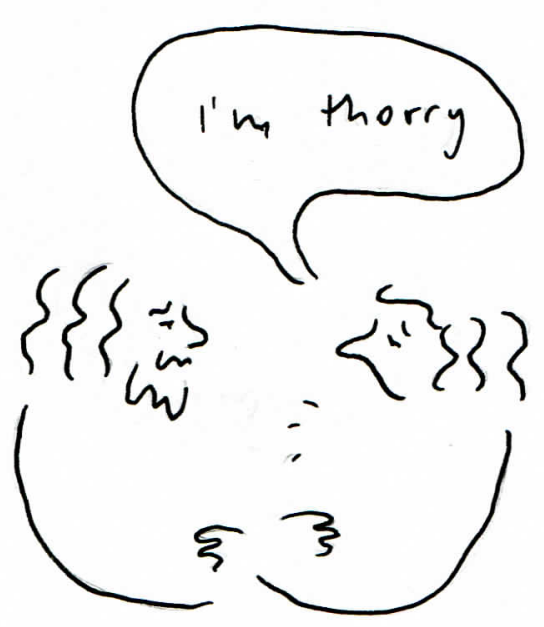

PAINFUL

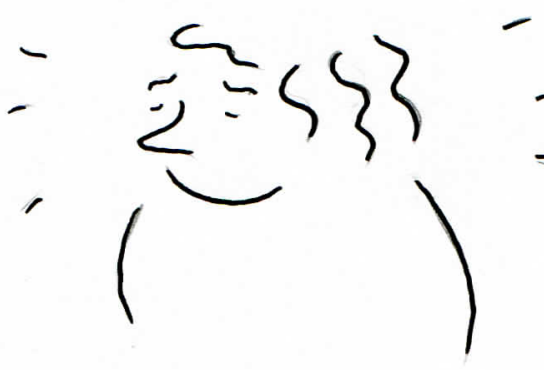



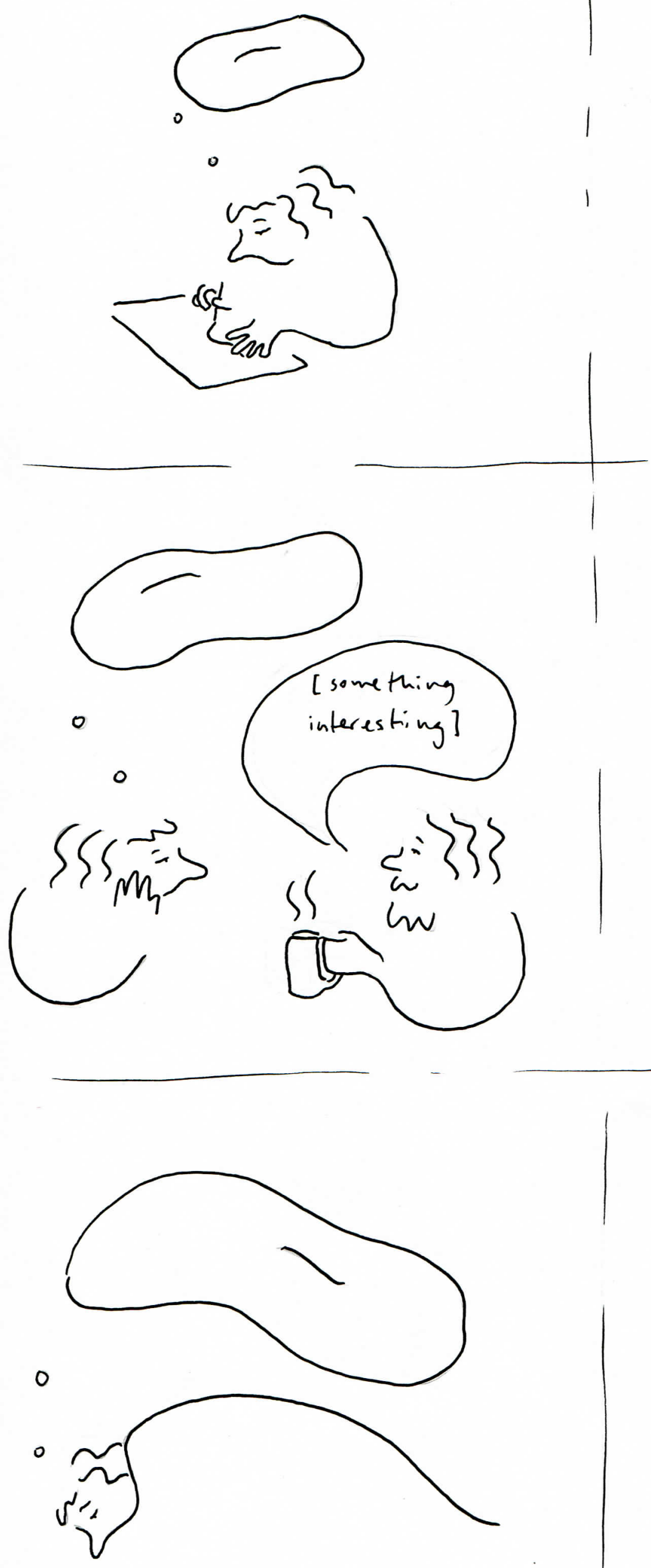
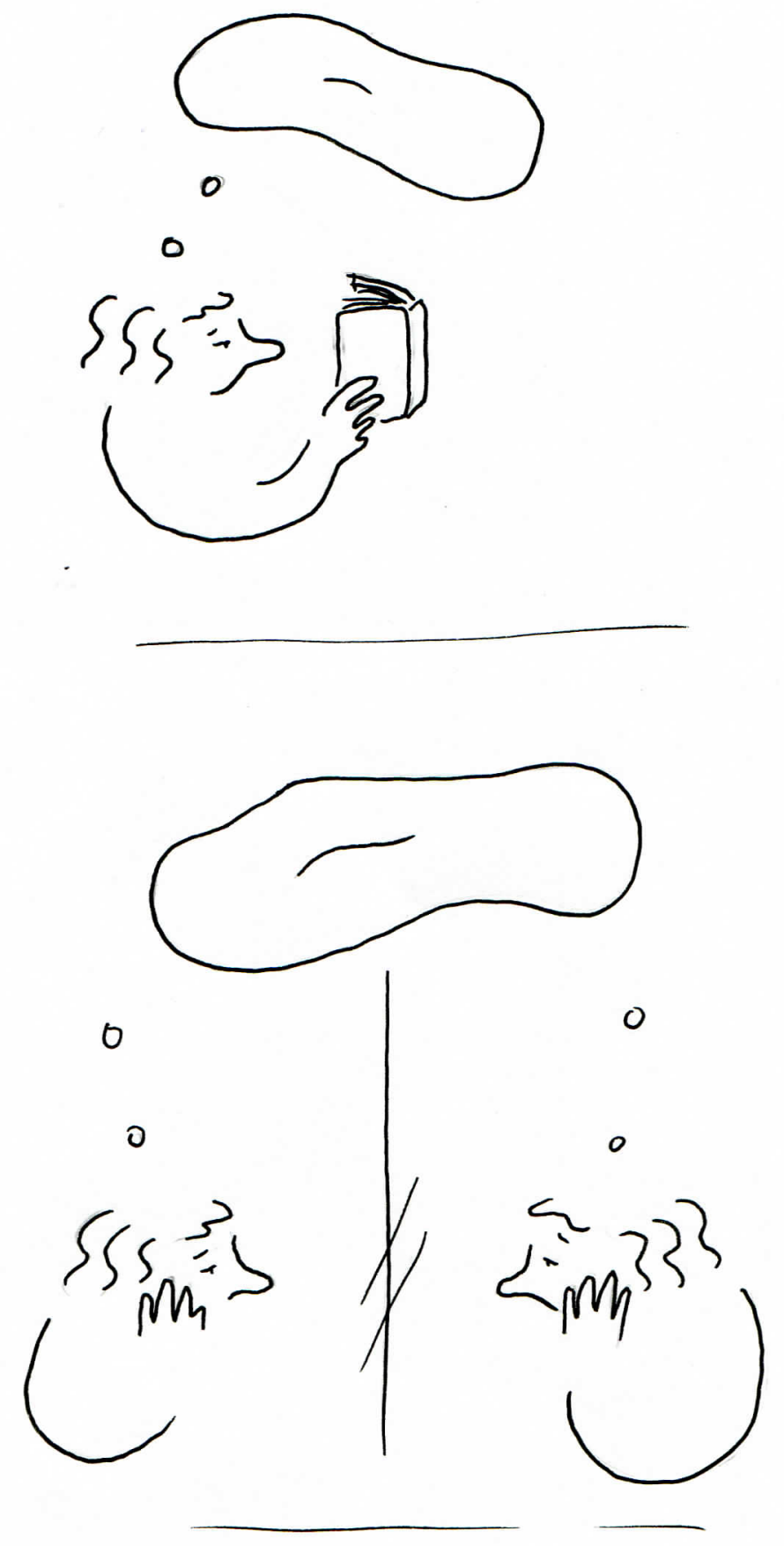

IT WAS ALL I COULD THINK ABOUT

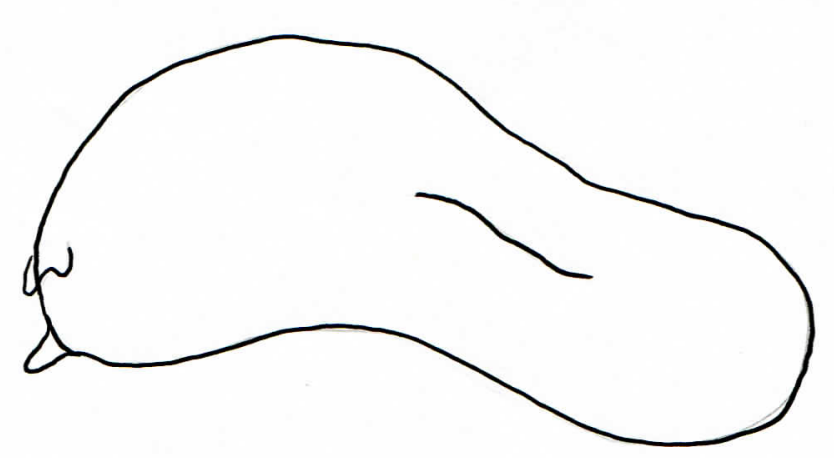


The condition was diagnosed as GEOGRAPHIC TONGUE (also known as benign migratory glossitis, lingua geographical, wandering rash of the tongue and transitory benign $p$ claques of the tongue) due to the patchy, map-like pattern on the tongue's surface:

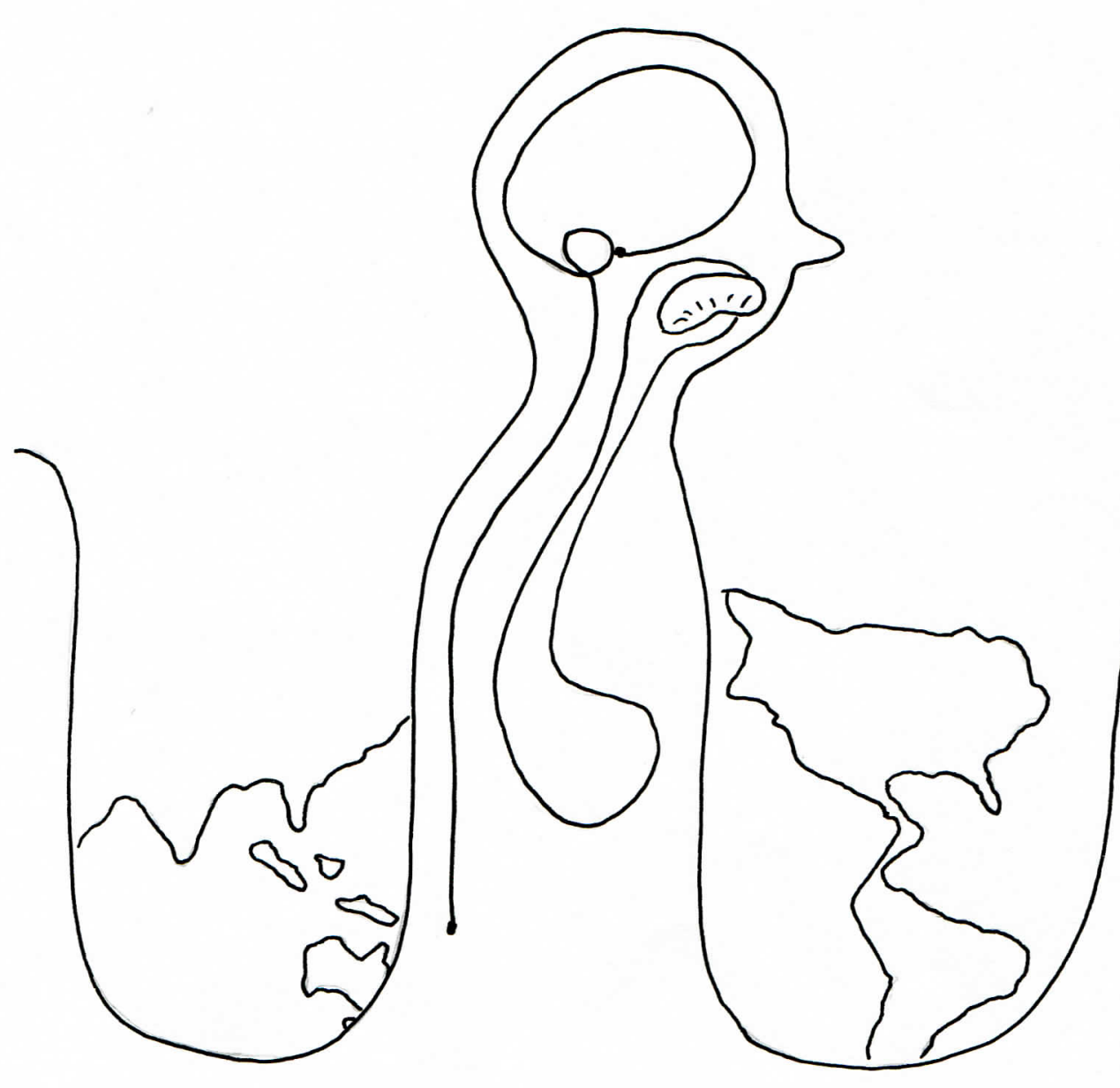

Causes are mostly unknown, or varied: vitamin deficiencies, hormonal imbalances, stress. 
THE BEST TREATMENT

WAS ASPRIN

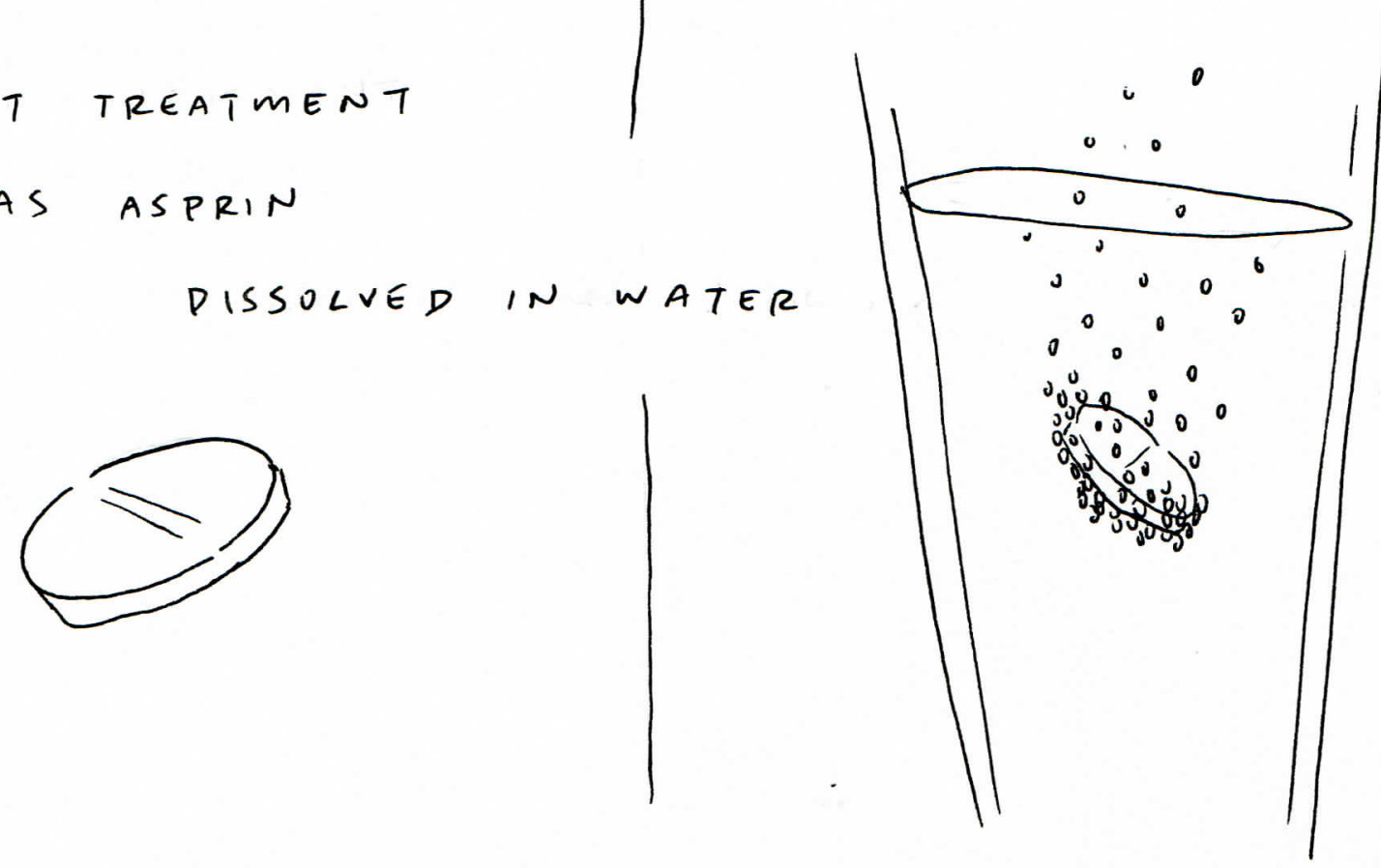

AND HELD IN mY

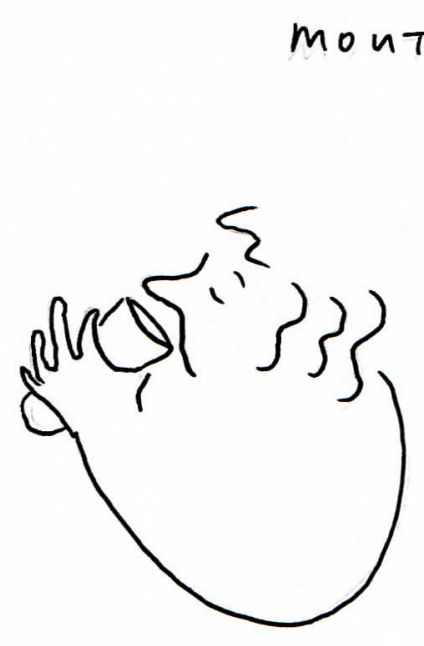

WITH MY CHEEKS PUFFED

O $T$

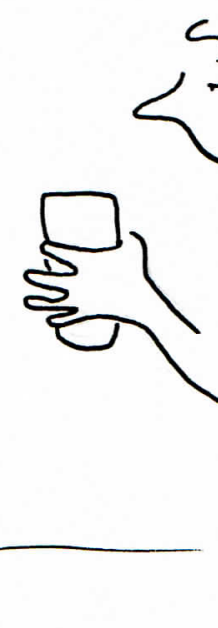

While I Stared into the middLe distance
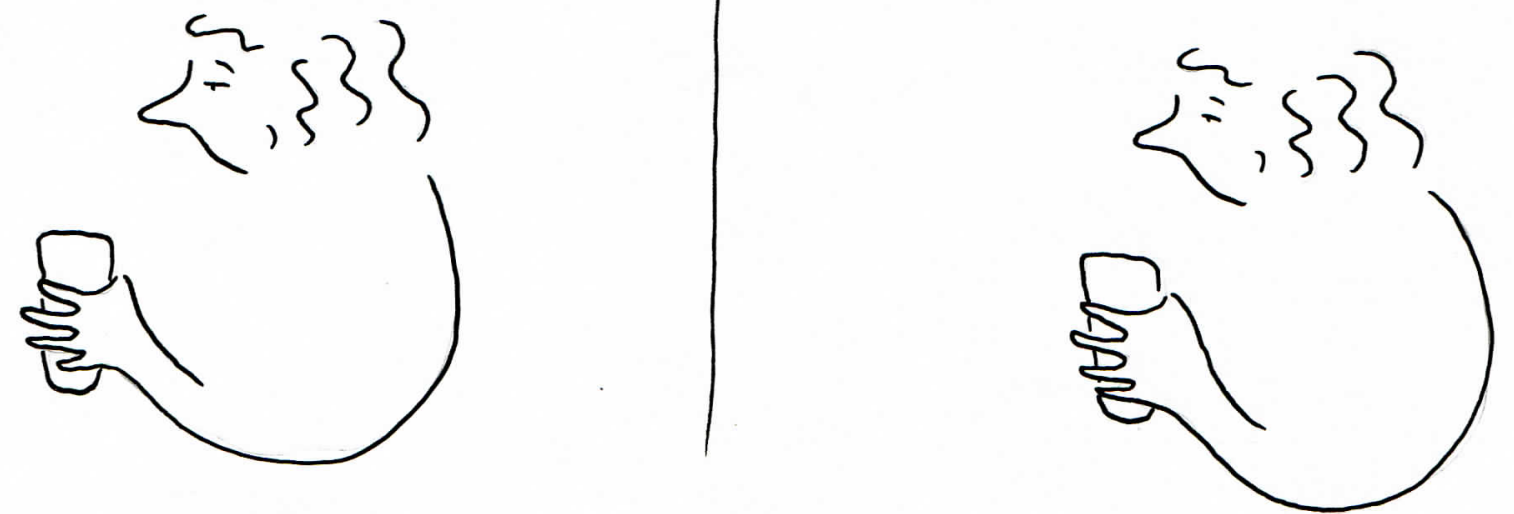


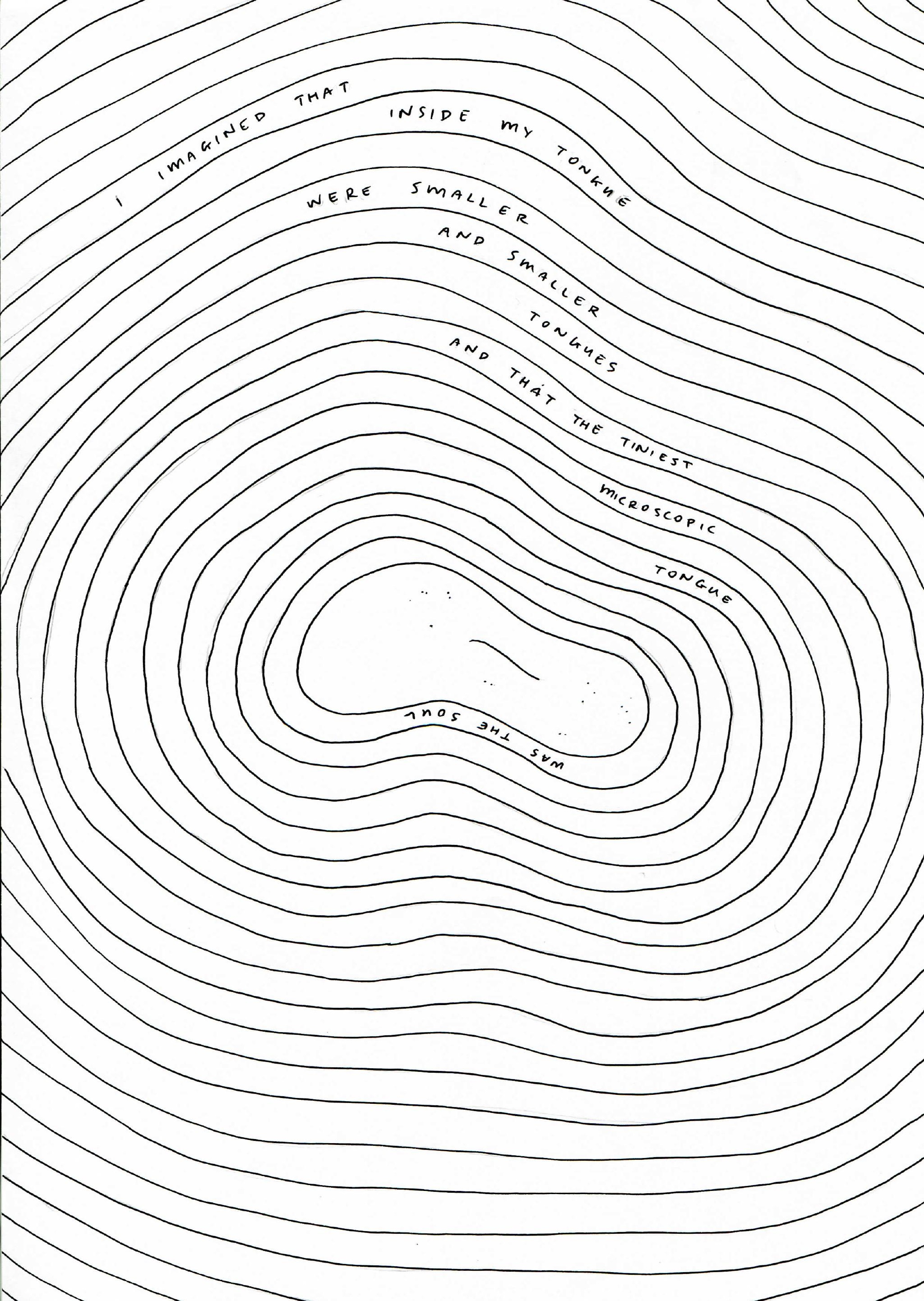


000

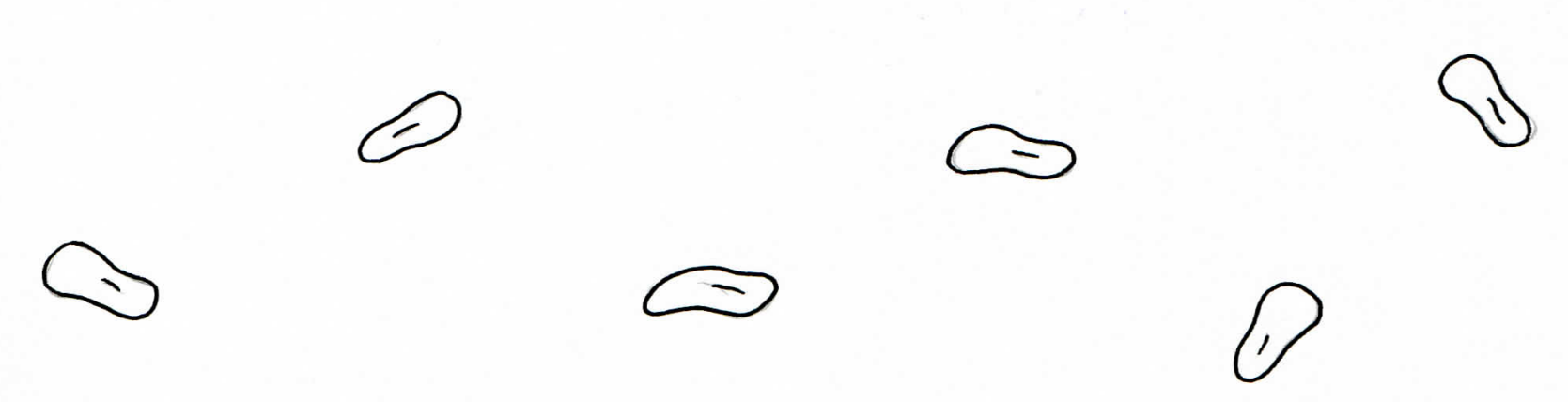

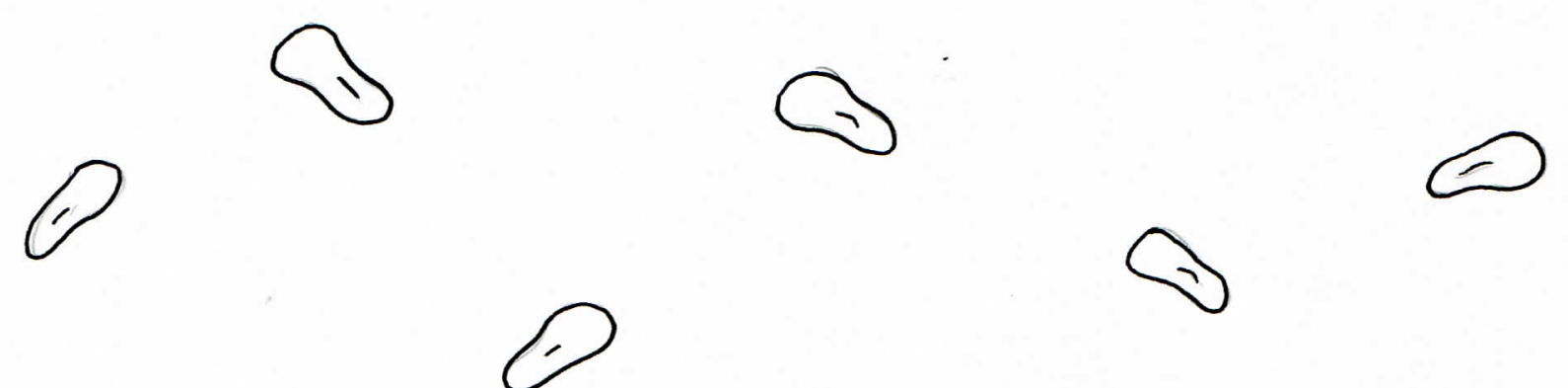

$$
\theta \quad 00
$$

$$
\begin{array}{cccccc}
0 & 0 & & 0 & & \\
0 & 0 & 0 & \\
0 & 0 & 0 & 0 & 0 \\
0 & 0 & 0 & 0 & &
\end{array}
$$




\section{Research Statement}

\section{Research background}

So Much Tongue is part of a larger thesis on sincerity and autobiographical comics. The thesis asks what it means to talk about sincerity in comics, and how sincerity is related to or differs from authenticity and irony. It looks at how sincerity in autobiographic truth telling manifests in openness and intimacy, in a kinder, gentler tone (than perhaps authenticity) through both language and gesture; through not only the cartoonist's words but through the cartoonist's hand, and handwriting, on the comics page.

\section{Research contribution}

The turn towards sincerity in pockets of the cultural landscape in the past twenty to thirty years has been noted in relation to poetry, fiction, film, fine art, and music, but little has been written on how this turn has manifested in comics. In wider studies of sincerity, comics are mentioned briefly (Magill 2012) or not at all (Van Alphen et al 2008). This research project examines how authenticity, irony, and sincerity have shifted in importance or preference within contemporary comics, focussing how sincerity is drawn out, so to speak, in autobiographical comics.

\section{Research significance}

The difficulty with sincerity and being sincere begins with the difficulty of ontology. It is difficult enough to know ourselves, to be transparent before ourselves, let alone express ourselves to another in a way that will be received as we intend. Comics are unique in that the verbal content of speech is expressed visually as corporeal. The verbal (and visual) content of thought is expressed in singular, contained moments, emanating from, but occurring outside of the body. This research contributes not only to comics scholarship on the conventions of speech and thought balloons but to ideas about mindfulness and the relationship between mind and body.

\section{Works cited}

Magill Jr, R. Jay 2012 Sincerity, NewYork: W.W. Norton \& Company

Van Alphen, Ernst et al 2008 The Rhetoric of Sincerity, Stanford: Stanford University Press 


\title{
Central Queensland University
}

\author{
Donna Lee Brien
} Women, birth, life and death: from the fictionalised diary of Mary Dean
[extract]

Biographical note:

Donna Lee Brien (BEd, Deakin; GCHE, UNE; MA (Prelim.), USydney; MA, UTS; $\mathrm{PhD}, \mathrm{QUT}$ ) is Professor, Creative Industries, and Head of Creative and Performing Arts Research at Central Queensland University. Widely published on specialist genres of creative nonfiction, with an emphasis on biography and memoir, her biography, John Power 1881-1943, the standard work on this expatriate Australian artist. A Past President of national peak body, the Australasian Association of Writing Programs, Donna is currently Commisioning Editor, Special Issues, TEXT: Journal of Writing and Writing Courses, and a member of the Editorial Advisory Board of The Australasian Journal of Popular Culture and Aeternum: International Journal of Contemporary Gothic Studies. Current research includes projects on a taxonomy of memoir, speculative and experimental life writing sub-genres, and the Contempoary Gothic. Her most recent book is New Directions in $21^{\text {st }}$ Century Gothic: The Gothic Compass (Routledge, New York and London, 2015) with Lorna Piatti-Farnell.

Keywords:

Creative writing - fictionalised biography - Dean, Mary (b.1869) 


\section{Introduction}

In the mid-1890s, the so-called 'Dean Case' caused a sensation across Australia. George Dean was a 27-year-old Sydney ferry master, a handsome, moustached hero who had been awarded a gold watch for his dramatic rescue of two drowning female passengers. In March 1895, on the day of their first wedding anniversary, George was arrested for the poisoning and attempted murder of Mary, his 20-year-old wife and mother to their 10-week-old baby girl. During the trial it was not George, as the accused, whose actions and motivations were probed; instead the behaviour, habits, personality and character of his wife was minutely analysed and criticised. This climaxed in defence counsel arguments that Mary had poisoned herself, but the jury still found George guilty and he was sentenced to hang - the mandatory punishment for attempted murder at that time. Despite the jury's unanimous verdict, a public outcry resulted in an inquiry and a royal pardon for George Dean. When it was revealed that he had, however, confessed his guilt to his lawyer, George was returned to gaol on perjury charges, although he never faced justice for the violence he perpetrated against his young wife. Accounts of the case since 1895 largely repeat these facts, perpetuating a focus on George Dean and the notable political and judicial figures involved in the scandal. Mary Dean's story has mostlly been forgotten and ignored. This is, however, far more interesting and, like many women lost to Australian history, the details of her life can help cast light on some current prevalent attitudes and behaviours.

\section{From the (fictionalised) diary of Mary Dean}

\section{April 1935}

My birthday. Always a day that starts me thinking about the past. Ma used to say I had my papa's eyes and his hair, but she never told me much about him except that he had been some kind of dealer and had left us. Sometimes I missed having a father, but I never thought about him much and later, when I saw how some of my friends' fathers went on, drinking and knocking everyone around, was glad we were on our own. Not that we ever were really - not with all those lodgers and uncles living with us.

I can also recall Ma telling me that when I was born, she said, then and there, No more babies. And, like everything my mother set her mind to, there weren't. Years later I found out that she had given birth to another baby girl more than twenty years before me, which means I have an older sister, a half-sister as it turns out, who I have never met. I have never been able to find out is she is alive or dead, but I pray we will meet, either here, or in the hereafter.

I must have been only four or five when we packed our things and moved up to Sydney. I can't remember where we lived at first, but by the time I was seven we had moved into a boarding house in Surry Hills. Ma could not find work. She tried as a barmaid, a waitress and a shop assistant, but the employers all wanted single girls, and young pretty ones to boot. Going out as a servant, taking in sewing or washing or the low kind of jobs many women had to do - like working in a butchers only to be 
paid in scraps of meat - was not for her. So, she put everything we had in hock and took out a lease on a house not far away in Riley Street. She set up a small greengrocer's shop in front where there had been a tailor's, and put out a sign for lodgers.

Surry Hills was fast filling up with long strips of narrow terrace houses and most everyone had big families, so I had plenty of friends my own age. Despite the building going on all around, there were still empty lots full of long grass and wildflowers and some had horses in them. We would stand on boxes and feed those old horses crusts and bits of carrot and rub their noses and torn ears. They worked hard, pulling heavy carts through the city streets, but they still let us pet and kiss them, and sometimes you would see them cantering around the paddock like ponies.

Some of the boarders were keen on my mother and like uncles to me, but some were strange and I was scared of them. My mother ran a tight ship and if anyone let out a flamin' this or blasted that or called someone a silly bugger, they would look sheepishly across to us and apologise, saying it came from being with men all day. Some of the young blokes were what Ma called fast, and I found out later that they were members of the gangs who roamed the city looking for trouble. Ma much preferred to have older men in the house - they stayed longer and were better at paying their rent. There was one old fellow who always wore his braces and hat in bed, which was funny, but he slept with a shotgun beside him, and Ma was worried it was loaded and would cause someone an injury. Then there was Sam who we found with three hens in his room, Ned who never - and I mean never - washed, Jerry who was arrested for bookmaking and old Patrick who, despite his decrepitude, was always trying to smuggle women in, or out, of his room.

My mother liked men, I knew that, but never trusted them. She always had a sweetheart in those days, some Johnny hanging on, and I know now she found her solace where she could. She could have married many a time, but she used to sweep me up and whisper in my ear, Just you and me, my little chick, just you and me. We don't want any nasty old rooster telling us what to do, do we? She often told me that her goal was to live independently, needing no one. If this century is really going to be different from the last, perhaps women, and others like her, will finally be given some respect for surviving as they did. As we did, despite everything.

Once, when things were really tight, we had to rent out my room and I slept with $\mathrm{Ma}$ in her big wooden bed. I had to go up quite early and in summer, when it was still light, I would look at all the different fabrics in her old quilt, dreaming of the dresses I would have when I grew up. I wanted all the trimmings too, hats and lace and parasols and little bags to hang from my wrist. Being a widow, Ma always wore black. She had her rings and a man's gold watch she wore inside her waistband. She popped those rings more than a few times, but we always got them back. The watch was our last ditch security it was only pawned when we were absolutely desperate. It was our insurance, and Ma always used to say our luck was on the turn when we rescued it back out of hock.

The lodgers meant the washing and cleaning was never-ending. I helped when I had to, but was glad when Ma would shoo me out of the house. Sunday was not exactly a 
holy day of rest in Surry Hills, but at least we never did housework, although we would open the shop if someone wanted something. The pubs sold drink through the back door and was drunk in our house, but I must say my mother always made me get tidy for church and sometimes would curl my hair in papers. I went to Sunday School from the time I was very little and loved the pretty teacher who was never cross. We used to get a prize if we learnt our verses, usually a card with a picture and a motto on it. I won one that we stood on our mantle and it burned itself into my brain. Blessed is the man whose transgression is forgiven, whose sin is covered. I never understood it. I do not believe it is fair that all criminals are forgiven. I don't see that their victims are ever blessed or otherwise compensated for their suffering.

\section{April 1935}

More rubbish from the men today. Dulcie's granddaughter, little Amy, is pregnant and the stupid doctor told her not to tell anyone. Not her mother, her sisters or her other close relatives, not her girlfriends or women neighbours, his reasoning being that we'd give her contradictory (and necessarily, to his mind, idiotic) advice. As if this isn't the exact time when a girl needs all the support and advice she can get. What I would have done without dear Ma during my terrible time I just do not know. I thought I was going to die, and the only advice George could offer me was to get an abortion.

I must have fallen in the first month we were married, and although I wasn't completely sure, I told George what I suspected. His reaction stunned me. I thought he would be happy, instead, he shouted at me, ordered me to get rid of it. They were the exact words he used. Get. Rid. Of. It.

He had heard talk, he said, of the various ways. He heard everything on the ferry. Women sat there and spoke in front of him as if he were invisible, as if somehow because he was working his ears weren't. There were medicines, he told me, regulating tablets. Well, I knew all about them. Sal had tried about a dozen different ones. She was sick as a poisoned dog but she still had her baby. I said there was no way I would touch any such thing, nor the Chinese herbs Madame Rose got for her girls when they got caught, foul mixtures which used to make their stomachs gripe so badly I could hear them crying from across the road. Don't let that happen to you, Ma would say, and I didn't. Anyway, I was married, so a baby was meant to be a joy.

But George wouldn't stop. He told me how back in Bathurst the girls would ask their men to hit them in the belly, or stomp on them, how they would bathe in freezing water or jump off tables trying to jolt the baby loose. I couldn't believe it, my own husband was sitting beside me, and urging me to throw myself from a tram or go to one of those dirty old witches, those so-called 'nurses' down in Woolloomooloo. But I wouldn't. I wanted my baby, even if he didn't.

He kept saying it wasn't his, and I thought about how once when I was still quite little I heard Mrs. Lee telling Ma about how the lady she worked for had been taken to the asylum at Rozelle - the madhouse she called it - for having someone else's baby. She said Mrs. Browne was a nymphomaniac. I thought this sounded dreadful although I 
had no idea what it was. We found out later that this poor woman had inherited a large sum when her father died and her husband spread the most awful lies about her throwing herself at every man who came her way. Mr. Browne had taken to locking his wife in her room, but when she tried to climb down a tree to escape, he called the doctors and had her taken away.

Lucy lived in Balmain for ages and she used to say that when the wind blew a certain way it carried the inmates' cries across the suburb. I know they used to do terrible things to you to try to get you back to normal, pull your teeth out, cut out your women's organs, force you to lie in cold baths for hours. Occasionally, I wonder if poor Mrs B. ever proved her sanity, or was locked up her whole life, or at least until her husband spent her fortune. She had three small children when she was committed. Heaven's knows what became of them.

\section{April 1935}

The first dead body I ever saw was Liza's. They brought her back from hospital and put her in the front room in a little coffin propped up on the tea table. I really didn't want to look but her Nan made me. Liza's little face was scratched up and her lips were swollen and strange. She had cotton wool in her nostrils. Auntie Jenny said I should kiss her goodbye, but I touched her cheek and it was stone cold.

That must have been around my eighth birthday because I remember being sad that Liza missed the party Auntie Jenny gave me. Jen was my mother's older sister and came all the way from London to visit and lived with us for quite a while, a year or maybe more, but I never knew exactly why. She had long red hair which she dressed in ringlets around her face and always wore the brightest colours. I can see her laughing with the lodgers, thinking back on it now I'm sure she was after a husband, but if she was she should have looked in flasher circles than ours. The men we knew were always broke, or in the process of drinking or gambling away what money they did have.

Auntie Jenny talked a lot about back home, I think she pined for the cool and the way they did things there. In the end, there was some misunderstanding between her and mother over Uncle Tom and she left. For years we didn't even get a card from her. But then they started arriving again, fancy gold printed birthday and Christmas cards, usually posted from where she lived in Cheapside, with the odd one from Brighton or some other seaside town. She always wrote that mother should send me out, but she caught a bad cold and it settled in her chest and she died not long after I married George, so that was that.

When I was ten or eleven, Sarah Kennedy came to the door one morning. Her mum'd had a baby in the night, but it was dead and she needed something to put him in. Ma found a little wooden soapbox and I went back to help. The baby was lying on a pillow on the washstand. He was like a little doll, but tiny, too tiny. Sarah and I lined the box with a bit of soft wadding and then Mrs Kennedy got out of bed and put her wee baby in it and fastened the lid down. She was crying all the time and gave us a letter and told us to give it and the box to the gravedigger. It was a long way to the 
cemetery but we didn't talk. We found the man, gave him the letter and waited while he read it. He told us to take the baby over to the church porch, and put it in the corner with the other parcels. I asked him what he was going to do but all he said was, Tell your mum it'll be alright. I remember how sweet the box smelt from the soap and us packing the wadding in so as wood wouldn't scratch his tender skin and how carefully we carried him up the big hill to the cemetery.

Most of all, though, I remember that pile of dead babies on the porch. 


\section{Research statement}

\section{Research background}

Violence against women/girls has a long history in Australia (Summers 1975). After 31 women were killed in the first 15 weeks of 2015, calls were made for national action. This speculative life writing, using facts from a case from the late $19^{\text {th }}$ century, is based on previous research that suggests that incorporating conjecture into biography can produce engaging and thought-provoking historical narratives (Brien 2015).

\section{Research contribution}

This extract from a speculative biography of a victim of extreme domestic and societal abuse highlights the potential of creative writing to bring attention to the unacceptability of violence against women (Brien 2000; Joyce 2014) and contribute to social change (Jasper 2008).

\section{Research significance}

The concept that drives this work has already attracted wide interest, with the author achieving national and international scholarly publication on fictionalised biography and its expressive potential. Of key significance here is the use of fictionalised historical biography to explicate a contemporary subject, delivering information in an engaging form, to highlight the issue and prompt reflective thought.

\section{Works cited}

Brien, DL 2000 'Blackrock and the problem of Australian true-crime fiction' Writing and The City (eds) F de Groen \& K Stewart, Sydney: UWS, 115-21

Brien, DL b 2015 'The facts formed a line of buoys in the sea of my own imagination': history, fiction and speculative biography' TEXT special issue 28 , http://www.textjournal.com.au/speciss/issue28/Brien.pdf

Jasper, JM 2008 The Art of Moral Protest: Culture, Biography, and Creativity in Social Movements Chicago: U Chicago P

Joyce, LE 2014 'Writing violence: JonBenet Ramsey and the legal, moral and aesthetic implications of creative non-fiction' New Writing 11 (2): 202-7

Summers, A 1975 Damned Whores and God's Police Ringwood: Penguin 


\section{University of Technology, Sydney}

\section{Barbara Brooks}

\section{Mutitjulu diary: notes from February/March 1996}

\section{Biographical note:}

Barbara Brooks is a writer, independent scholar and lecturer in writing. Her first book, Leaving Queensland, was published by Sea Cruise, a small art press. She has published a biography of a major Australian novelist, Eleanor Dark: a writer's life (Macmillan, 1998). Her essays and stories have been published in the US, UK, Europe and Asia as well as in Australia. She has received grants and fellowships from the Australia Council, Varuna, Asialink, Watermark and Bundanon. She has a Doctorate in Creative Arts from the University of Technology, Sydney, where Verandahs, her novel as fictional memoir, won the UTS Chancellor's Award for an outstanding thesis. Extracts have been published in Heat, Griffith Review, Off the Edge (a Malaysian magazine) and Outskirts.

\section{Keywords:}

Creative writing - Journal writing - Creative nonfiction - Uluru - Mutitjulu Pitjantjatjara 


\section{Prologue}

In 1985, I spent three months in Alice Springs, and visited remote communities. I met and talked mostly to 'white advisors' - lawyers, anthropologists, linguists, arts workers - but also to indigenous people and overseas visitors. I had thought that the cities were where everything happened in Australia. I realised then that at the heart of our relationship with this country is the following question: with whom and how do we share this country? The question raises the issue of how to write in a way that acknowledges two histories, acknowledges indigenous presence and lives. Writing about my visit, I wanted to show the complex issues that created a confrontation between white European law and traditional law. I wanted to tell a story about a court case, which was difficult, even impossible, given issues about privacy and the ownership of stories, issues that indigenous people confronted every day. Eleven years later, in 1996, I obtained a permit from Pitjantjatjara Council to stay in the Mutitjulu community at Ayers Rock, with a friend who was the liaison officer between the community and the Uluru Ayers Rock National Park. I heard many stories; people shared stories with me. To tell these stories would be inappropriate without permission and context. What I could do was to say what I observed about place. I tried to report rather than judge, to describe rather than romanticise, though I use images and poetic language as a way of creating a portrait in words, and I don't want to sound humourless. Point of view and subjectivity have their own life.

\section{February 1996}

It's sunset, and outside the kitchen window Ayer's Rock is changing colour from red and ochre to lavender. This is our first night in Mutitjulu, the Pitjantjatjara community near Ayers Rock, south west of Alice Springs. Outside, the wind has come up; things are blowing around and banging; doors creak inside; plastic bags, hanging bat-shaped, rustle and flap in the trees. The wind sings in the trees which are small and spiky like up-ended straw brooms or dish mops.

We stepped off the plane this morning, under an enormous sky with high cloud, into heat so dry it sucked us up in one slurp. If you come from the coast, it feels as if there's been a mistake: someone turned the central heating up too high, like in a department store in London in winter. We stepped out of the plane to a surprising blue and red and green landscape. But which way was out? I had a momentary feeling of claustrophobia, remembering that the sea was so far away. What was there this way? Country. That way? Country. Every way, miles of country. Soon the landscape itself captured our attention.

$\mathrm{J}$ took us to the Cultural Centre, where we watched videos of people talking about ngura (rolling the rrrr), the country; the tjukurpa (more brisk rolling $\mathrm{r}$ sounds), law or dreaming or knowledge; people dancing, singing, telling story. An old Aboriginal man told the story about Lasseter dying in the desert, pining away for the loss of tea, bread, sugar. Women dancers carved long furrows in the red dirt.

The Cultural Centre was low and curved, all brown wood, red concrete, earth walls, earthed yet light: those brown sheds, Marcia Langton called them - where Gaudi 
meets the $y u$ in central Australia? Inside: the intimacy of watching women painting each other's breasts, and the request not to climb the Rock. Outside: red soil, piles of brushwood as windbreaks, and the Rock rising in the gap between the buildings. We drove past the Rock and looked at its shapes and textures, caves and bulges - we can't take our eyes away.

We saw kurkaji or tinka - a lizard, sand goanna or desert monitor - outside the Ininti store, where we admired or gagged over t-shirts and souvenirs. The community store sold truck tyres, t-shirts, nectarines, coconut milk, ice blocks and frozen, furry kangaroo tails.

\section{March 1996}

It's morning in the Mutitjulu community. The house where I am staying is so close to the Rock, we can see it from the kitchen window, and walk to the base in fifteen minutes. I'm fortunate to have a permit to stay here.

On Monday night at sunset, we walked to the Rock from J's house, along a path through mulga bushes and brush with grey leaves. The sky was a soft blue and the moon had risen, close to full. The community was nearly empty, because of a big funeral. A low band of deeper blue appeared along the horizon until the sun disappeared behind the Rock. The sky shaded into soft apricot, and the moon started to glow. The face of the Rock glows at sunset; dozens of cars and tourist buses come to the approved parking spots - sunset viewing spots. The cameras click.

As we turned to walk back, picking desert plums and drinking water out of plastic bottles, the moon grew brighter and the first star came out above the Rock. We walked back through feathery brush that was black against the sky now, the sky that was still glowing. We heard the sounds of cars and voices in the distance, people coming back to the community after their ceremony, laughing and talking. A woman ranger stopped when she passed us on the road, and flashed her torch at us, wanting to know who we were.

This morning, the flies are out before the sun is up. The sky is huge. Pink and orange along the eastern horizon, colours reflected on clouds, and on the Rock. There's a long sweep of curds and wisps of cloud, and, above the Rock, a weak moon, nearly full, slips in and out of view. Flycatchers swoop and circle around me in the air like acrobats as I walk along the first track, chasing after insects; we must attract the insects: these birds are always diving in loops around us and shooting past. The crows are big, glossy and healthy-looking.

The wind starts. That wind sound is the desert-country sound; I notice it here because of the silence. Plastic bags flap in the wind, debris from the rent meeting before we came. A woman walks slowly towards the store, accompanied by dogs, while a white Toyota circles around the dirt tracks that run across and around the community.

Now the sky is full of noise. There are two planes: one, the sunrise shift of the scenic flights, perhaps the morning flight over Uluru and Kata Juta, the Olgas; the other, small and black, seems higher, a commercial flight. 
On the other side of the community is the "straw house", the house where Bill Harney lived when he was a ranger. Anangu are camped on the side of the road there. I hear the kids talking and laughing, and see the shape of an adult standing with a blanket held around them.

The sun hits the Rock and makes it glow for a few minutes before disappearing behind cloud. Trails of cloud spread across the sky, fanning out from the east. The white Toyota goes into the Works Depot, and a motor starts up, perhaps a generator. I walk back towards the house where I'm staying, noticing the cross on top of the church for the first time. On the way, I turn off the sprinklers that water the small trees, and a bird somewhere in them makes a long trilling sound. The light has become uniform now, stronger and clearer, and the Rock and the soil look paler, as if light bleaches them. The sun emerges from a layer of cloud above the horizon and lights the tops of the trees, and the undersides of the leaves that are silver in a softer light, and were bronze a few minutes ago, turn green again.

The white Toyota goes around again. I hear it over the sounds of dogs barking, water running inside the house, the same piece of black plastic we saw the day we arrived flapping in a tree across the road. Then someone coughing, an asthmatic cough I think, and a trill of bird sound. The planes again. And behind it all, that wind. All these noises overlay a deep still quietness, the quietness of space and slow processes of growth and decay, the quietness contained in an enormous bowl of sky, a horizon that comes down to your feet - something I feel as a spaciousness that is not empty but present and powerful enough to slow things down to its own speed.

It's twenty to eight. The sky is deep blue behind white cloud. The Rock changes colour: red, ochre, lavender. The striations and markings, brain-like patterns, hollows and caves show up more at certain times, as the light catches different aspects; and the size seems to change, depending on the point of view and time of day. There are jokes about Anangu pumping it up every night to satisfy the tourists. Here, this morning, the Rock seems huge, and I hear a car radio playing $\mathrm{C} \& \mathrm{~W}$, and someone whistling inside the house. I feel the first heat of the day, and I go inside.

People move slowly here, in the heat, against the horizon, like the woman I saw walking to the store, but when they speak Pitjantjatjara, it's a fast, expressive language.

Pukulpa Pitjama Ananguku Ngurakutu, the signs say, Welcome to Aboriginal Land. In this multilingual spot we listen to one of the traditional owners, Cassidy Uluru, telling a story about the tjukurpa in Pitjantjatjara, while a younger Aboriginal man translates into English. The visitors speak Japanese, Italian, German, Dutch, varieties of English from north of England to Texan; locals may speak other similar languages, too: Yankunytjatjara and Ngaanyatjarra.

Anangu, as the Pitjantjatjara people call themselves, are the traditional owners of this World Heritage listed Uluru-Kata Juta national park, to which they were given title in the 'handback' in 1985, and which they now lease to the Commonwealth Government. At the handback ceremony, Yami Lester, chairman of Pitjantjatjara Council, said to the Governor General, Ninian Stephen, I'm glad you're here to see the Rock for the last time. It was a joke with an edge. We are told, he said, that Aboriginal people are 
going to take it away from other Australians. Anangu leased the national park to the Commonwealth government, to ANCA, and joint management benefits everyone. Anangu are happy. There are posters in the Cultural Centre of Jennifer Taylor's painting called Working together, with brown and white people sitting round in a circle, round a table or a campfire, a centre of some kind, maybe the Rock itself, and beside and behind them, the brown footprints of Anangu rangers and trainee rangers, and the white shoeprints of the white men and women who are park rangers.

Training and learning goes both ways. Edith Imantura Richards (1994) taught the white rangers to look after plants and animals. Edith can tell the difference between the tracks of different kinds of snakes in the dust. Talking about the plants and animals is inseparable from talking about people and country. Anangu stories retain knowledge of animals now extinct. 'You have to talk strongly for the ground, for the stories, for the hills, for the trees, for all the animals that walk around in this land, and for all of their names. That is why we have to talk strongly about the Tjukurpa, for the continuity of life.'

I have been writing down place names in language: this country was named, and renamed, and now is being named again. Imanpa, Apatula, Pukatja (formerly Ernabella), Yunyarinyi, Wongellina, Pipalyatyare, Mimili, Kaltjiti (or Fregon), Amata, Iwantja (formerly Indulkana), and Mantamara over the WA border. The words on the paper don't carry the music of Anangu voices. We walk around here practising words like tjukurpa (rolling rrrs), panpanpalaya, kalaya junta, words we've heard in the course of Anangu story-telling. We are trying to learn about this place. 


\section{Research statement}

\section{Research background}

The context of this work is my interest in writing about place and people in Australia in a way that acknowledges Indigenous presence and history. To research this, I visited Central Australia and read Indigenous and white writing. These journal notes come from a 1996 visit to the Pitjantjatjara community, Uluru. It questions how to record Pitjantjatjara life in a place that is both private (the community is closed) and sacred (a number of song lines converge on the Rock and areas around it) without transgression.

\section{Research contribution}

Creative nonfiction is used here to document and map place without a dominant narrative overlay. Sinclair (qtd. in Self 2007) distinguishes between the flaneur, the city walker, the walker who perhaps gets lost and the purposeful walker. My walking has a purpose; it is a journey of discovery. But I am lost in the space between cultures. The content of this extract from the 'Mutitjulu Diary' represents what I learned from my research, my visit to Mutitjulu, and my conversations with people there. 'Mutitjulu Diary' contributes to the volume of writing about this community.

\section{Research significance}

Wright (2002) speaks of writing that acknowledges all life is sacred. She quotes Galeano on rescuing the word from silence and paying respect to language. I start from a different silence, believing it is essential for writers to start from a position of acknowledging that we share this country. While not everything we write is about Indigenous presence and history, it is part of the context in which we write. I have published work in the genre of creative nonfiction, and incorporated other writing about my visit to Mutitjulu into my DCA thesis, which received the UTS Vice Chancellors Award.

\section{Works cited}

Richards, EI 1994 in S Breeden (ed) Uluru, East Roseville, NSW: Simon and Schuster, 90

Self, W 2007 Psychogeography, London: Bloomsbury

Wright, A 2002 'Politics of writing', Southerly 62 (2): 10-20 


\section{Deakin University}

\section{Marion May Campbell}

\section{Snap}

\section{Biographical note:}

Marion May Campbell has written novels (Lines of flight, Not being Miriam, Prowler and Shadow thief, now available as e-books though Wuthering Ink), poetry, theatre and criticism. Her cross-genre work, Fragments from a paper witch (Salt 2009), was a finalist in the Innovation Category of the 2010 Adelaide Festival Literary Awards and her novella konkretion, about failed feminist revolutionaries, appeared in 2013 with UWA Publishing. Her critical exploration Poetic revolutionaries: intertextuality \& subversion appeared 2014 with Rodopi. Marion is Associate Professor in Professional and Creative Writing at Deakin University, where she is working on creative and critical fronts on the radical tradition of prose poetry and the poetics of the fragment as challenge to the heteronormative subject of consumption.

\section{Keywords:}

Creative writing - second person - metafictional romance - Queer desire 
As we meet, before we've felt each other's body unfold and reconfigure, I guess there'll be a silence like this - with only our breath lapping ear to ear.

I'm ready now, as the days fly from the desk calendar and the seasons pulse past. I'm laying this down to calm my heart, I think. Why such quickening ... Is it because of the others, all the stories that had the wrong tone, the falsetto of ventriloquy or something? Or maybe this extreme feeling is more to do with the cumulative relay from story to story - all their gathered intensities. The long preparation for you, breathing now just behind the screen, the near contact of fingers, lips, breasts, bellies, thighs. It's not as if I haven't always looked for connection, anywhere, everywhere. And if there had to be an after-you, if the unthinkable were to happen and you were to die before me, I don't suppose that even then I'd give up. I like to think that until the last breath, even if it were to be a slow emphysemic drowning, I wouldn't give up on connection. It's what you show me with the fierce flame of your belief in this diminishing life we share.

The child who runs past my open door, might still, in a brief smile, make a fleeting connection and send a luminous backwash over all that I call memory. I used to think, oh come on, where's your imagination, of those teachers in primary school who set us these compositions - it was always a composition, never a story - where we had to voice the memory of something passed from hand to hand: an old boot, a school satchel, a flute, a doll's house. You had to tell the story of the thing in the first person. But now I'm starting to understand these relays, why it never begins or ends with one person, this love story.

We recognised each other.

And it was seismic.

We've used all of these: tremor, quake, Vesuvius - like there's no hyperbole for us.

But it's your words arriving in bold that call up your lava lady.

And everything half rhymes with this laughter of recognition.

And right now in this dream we're about to go snap.

We're both wearing French sailor's jumpers. Once they sold for a song in navy surplus stores, like in Toulon where Marcel bought us one each, for himself and for me. The coarse wool prickled my bare skin but I wanted so much its look and its jaunty, unbuttoned feel on my shoulder that I turned that scratchy infuriation to pleasure. He was a dancer; perhaps a bit of the thug in his flares of temper, but along with that, he had a feline finesse. You know those exquisite adjustments in free-fall. Oh it's hardly an oxymoron, the aristocratic thug: a father from the Corsican-Marseillais milieu, a mother from Vietnamese royalty - one of colonialism's strangely beautiful fall-outs. He had coarse, blue-black hair, high broad cheekbones, a sprinkling of dark freckles. I loved his sailor's swagger, never questioned its authenticity or its affectation - such things didn't come into our couple, which was quite frankly a masquerade. He called forth the sailor in me, the girl whose sexuality was schooled in reading Jean Genet and that you recognised in me just now. We licked the lemon sorbet cones that we held in our outside hands. We walked like new lovers, my left hand and his right, in the back pockets of each other's jeans. That morning, everyone on the quays of Toulon, every sailor, smoker, idler in the old military port, was sexy and complicit, eyeing off his androgynous beauty. I was a pale mouse compared with him, but I think I caught his 
glow. We were young and our animal insouciance masked all our faults. I see now that his teeth were already blackening. That morning still breathes its Gauloise smoke through the knit of this jumper. That love, as sketchy as it might've been, still speaks to this sudden possibility now, to this snap of recognition.

The sailor's jumper I'm wearing is actually Marcel's, a bit big, I know, but you can read his torso from it. It was moulded to him and now it hangs on me like that old story, like a sort of comfort rug. My own I passed on to a girlfriend who found me in the end too insistent, too invasive, but with this one, anyhow, I've long since overcome the prickling.

It was just after the end of year exams and, exhilarated with the first blast of summer heat, I'd walked from Kingsford to Taylor's Square in Surrey Hills, Sydney, and there in the window of this guys' boutique I saw them, the perfect pair of white sailor's pants. Their design invited the hands to slide into the slanted pockets under the buttoned frontal flap. They were tightfitted over the belly, buttocks and thighs, and then widened extravagantly into the bellbottoms. I'd had a thing about uniforms, which should shock me now, since I like to see myself as small-time subversive, but what you became in a uniform had always fascinated me as a kid. When and where I grew up there were no men present but on every mantle piece they were framed in uniform, their faces shadowed by peaked Air Force or Navy caps. I remember thinking you could just pinch these photos from other people's albums and say, yeah, that's my dad. I was going be a pilot or a sailor and the uniform would make me the beloved of my mother, since this seemed to be what her vague green eyes dreamed of, someone in a uniform. So that summer in Sydney, and then in Toulon, I stepped towards the sailor whom, decades later, you hail in my dream.

And I start talking to you, I've got to admit, because I guess I've come to a halt in my imagination. I've found nothing in the vault, nothing in the cellar. So I've come down to this crypt that smells thickly of the warm earth. Following the cat that eludes me, even here in this dream, I find a ladder with broken rungs. I have to take the ladder down, down, falling where the rungs are missing. Following the cat-shape, cued by her exquisite adjustments in free-fall, through the earthy darkness, here, I find myself on the restaurant steps, at another level again, in some other country.

And here you are too, in your French sailor's jumper - snap. Above its stripes I look into your big face, with the straight, declarative nose and jaw, the strong unplucked, black eyebrows, the wide spread of the gorgeous mouth, the skin dark in this uncertain night. I can only guess at your eyes. I feel them as vast and blackly tidal and I'm not sure if I've already given myself over to their pull. The flashing, even teeth are an after-image.

It must be the break in your shift: and under the knit of the sailor's jumper, your free breasts rise and fall, and below, your long thighs are sprawled in the cook's black-and-white checked pants. As you watch me, you balance your fag on the step-edge and pick up this small purseshaped clay thing. You blow into it, soft, soft, and it's a breathy sound, almost like you're Prometheus lighting that first flesh fire. You pat the step next to you without a word and again blow into the little clay flute. There's a smell of decay here, but a good one, like of composted vegetation, and I sit down close to you. We're in some sort of underbelly, fertile and secretive. Our silence takes form through your flute. After a long time, you say, thought I'd never smoke again, and I didn't for two months and a bit, but when the news came about 
these symptoms, I thought fuck all of that, and went straight out to buy tobacco and papers. So taking up the fags again, I just wanted, you know, to slow myself down, to stretch time. Needed to go slow.

Now I feel what you mean, feel the word slow applied like a soft palm to my brow, and a drugged heaviness takes my limbs. The darkness turns around us, padding the edges of the semi-circle of light. Like a big captive cat on a leash, it goes round and round, this slow softness. You blow your soft music again. Just one night with you. But it's the hot darkness that has materialised between us and the cat is real, not a figure at all, and her eyes are highbeam golden and her ribcage ripples the bronze Havana coat and she is purring deeply and our hands touch her there, to take in the vibration, and now they are laid each on the other and I feel the weight of yours. Her face is a chiselled wedge, swivelling from you to me. Your hands open, your fingers mesh and lock under the cat's belly and raise her up and you sling her over your shoulder and she looks back at me and I follow.

It's not so much a restaurant as a bar where you do snacks for regulars who stay on. A woman with dazzling white hair and olive skin turns smiling to the ragged auburn one with nostril diamond, and you say, I had to ask her in because we were, like, you know, snap with our sailors' jumpers. Yeah nah, how could I not? You laugh.

We see now that there are many ways for us to love, as far-fetched as they might've seemed, and here we realise something so much larger between our keyboards and our screens. Your flute answers in your dream and calls up mine: its breath brings in the encounters, the costumes, and the rhymes. These rhymes make new folds where there'll always be something else for the next story, the next time, to make us go snap.

But my love, perhaps soon, when we finally meet, we'll have no use for these words. There might simply be in this fold, this abeyance - the miracle of our shared breath, of this silence lapping ear to ear. 


\section{Research statement}

\section{Research background}

Butler (1990) theorises that some writers explore sexuality as reiteration and performance. But how to write the erotic encounter between reciprocal readers whose bodies are caught in the lag of longing at the onset of death? Can dream and masquerade be enlisted to the task? The second-person address can be manipulative, associated as it is with the didactic. While it is kept in reflexive play in some high-modernist metafiction (Calvino 1979), and Wittig (1973) deploys the metamorphic potential of the lesbian I-you, how might the second person enable intimacy and reflexivity at once?

\section{Research contribution}

'Snap' deploys the queer cliché of becoming-sailor as a trope for recognition in the amorous encounter and literalises the 'copycat' as its catalyst. As Girard argues (1973), the human is foremost mimetic: this story makes its claim for originality and authenticity of connection through the playful recycling of cliché.

\section{Research significance}

'Snap' eschews the relative affectlessness of some metafiction by staging an amorous approach under the shadow of mortality. It exploits the liminal moment of modernist short fiction to summon the 'manifold' of experience. Here, love opens a space of intertextual resonance (Costello 2007), including motifs of Genet (masquerade), Duras (haunting) and Maurice Blanchot (the infinite approach), by writing the threshold of encounter as the intensive silence of wonder.

\section{Works cited}

Butler, J 2006 [1990] Gender trouble: feminism and the subversion of identity, New York: Routledge

Calvino, I 1998 [1977] If on a winter's night a traveller, W Weaver (trans), London: Vintage

Costello, M 2007 'Textuality, mutability and learning to write', TEXT 11 (2), at http://www.textjournal.com.au/oct07/costello.htm (accessed 24 September 2014)

Girard, R 1973 [1972] Deceit, desire and the novel: self and the other in literary structure, Y Freccero (trans), Baltimore and London: Johns Hopkins UP

Wittig, M 1973 Le corps lesbien, Paris: Seuil 


\title{
University of Wollongong
}

\author{
Shady Cosgrove
}

\section{Dumpster diving: a family excursion \\ (the researching parent/parenting researcher)}

\author{
Biographical note: \\ Shady Cosgrove is a Senior Lecturer in Creative Writing at the University of \\ Wollongong. Her books include What the Ground Can't Hold (Picador 2013) and She \\ Played Elvis (Allen and Unwin 2009). Her shorter works have appeared in Southerly, \\ Overland, Antipodes and Best Australian Stories.
}

Keywords:

Creative Writing - memoir - writing process - research - parenting 
We've just arrived in Brooklyn. It's late and slick clouds threaten rain. The 3-line isn't running from Franklin Avenue - there's track work on - and a herd of buses have already groaned past, jam-packed with passengers. The drivers stare straight ahead, pretending they don't see all the waving arms. Someone throws a rock at the back of one and it bounces to the ground.

A large woman in a bright dress ambles past, stepping down onto the street to move around the crowd. 'Wouldn't be treating us like this in a white neighbourhood, that's for sure.'

Hostility vibrates in the air. We're standing on a wide sidewalk but at least two hundred people are waiting and a fight's breaking out. Only six or seven are game, but it's enough for a wide circle to open up. Maybe someone's pushed ahead, I don't know. The shouting is fierce, voices match up against each other. It's dark now and the streetlights are meek.

I'm travelling with my partner Scott and our four-year-old son Seattle. My heart is pounding and I feel like an idiot: no idea where I'm going, pulling a trundle-bag that belongs at an airport.

Finally, a bus pulls up, doors sigh open, and we're swept on board before I can figure out if we're heading the right way. I'm wedged up against a silver rail that reaches from ceiling to floor, one arm hooked around the pole, opposite hand clutching Seattle's shoulder. Scott has been shoved up the back. We make eye-contact and then he disappears into the throng.

Seattle pulls my arm. 'Mama, I'm hungry.'

'I know, mate. We'll be there soon.'

An older woman, sitting on the opposite side of the bus rubs her hip. She smiles, eyebrows lift with a 'we're-all-in-this-together' shrug, and I'm grateful for the kindness of eye contact.

'This stop at Kingston Avenue?' I ask through the bodies between us.

She nods.

Someone's yelling outside. More jostling. Now the driver's calling the cops.

We're staying with a friend in Crown Heights, a neighbourhood in the middle of Brooklyn, known for race riots in the early 1990s. The majority of the population is West Indian and African-American but there's a large minority of Hasidic Jews as well. Hasidic Jews are ultra-orthodox. The men wear black suits, long beards and brimmed hats while the women wear modest skirts and wigs (even with the wigs, sometimes they shave their heads beneath, depending on the community).

Eastern Parkway, a tree-lined thoroughfare with a lovely wide sidewalk, seems to be the dividing line between the white Jewish neighbourhood and the black Caribbean one. We're staying about two blocks into the Caribbean side because gentrification is bringing white non-Hasidic folks to the area, something I have mixed feelings about. 
I've travelled to Brooklyn because I'm researching a novel I want to write about dumpster diving, squatting and alternatives to capitalism. New York is a global hub for this stuff - especially for freegans. Freegans are people who question the role of money in their lives and try to live without it - scavenging and bartering whenever possible. They've attracted media attention because they offer dumpster diving tours, and they're people who choose to live without money - many of the long-term freegans I met had been unhappily employed (teachers, office workers, etcetera) before giving up money. In the next few weeks, I'll go dumpster diving along Wall Street with the New York freegan chapter. I'll also tour squats and community gardens in Alphabet City with the Museum of Reclaimed Urban Space. I'll learn foraging techniques in Central Park - how to spot edible stuff that grows in the wild, everything from yellow wood sorrel to cattail leaves. I'll ride a bike through Manhattan with bicycle activists. I'll check out sustainable rooftop farms and volunteer at the Really, Really Free Market (where everything really is for free). I'll visit the Fixers' Collective, a group of tradesmen who fix lamps and pots and suitcases (anything that anyone brings in) because they're committed to keeping stuff out of landfill. And all of this - even the midnight dumpster diving excursions - I'm doing with my family.

I'm interested in how writers research their material, and it seems to be a gendered issue. That is, if women are committed novelists who need experiential research to write novels, and they have young children who need to come with them: what issues does this raise? I take on board that I'm writing from a privileged position - I work in a university context and was awarded study leave. Yet, even with this support, I couldn't find one writing residency in Australia, the United States or Europe that catered for a parent with a small child, even though I had another responsible adult available for full-time childcare. On one hand, I understand: other writers want tranquillity and space to write, and that's not something usually associated with small children. But the message then becomes: women can be mothers or they can be writers but it's too much to expect you can be both. And even more problematic is how I came to internalise this - sometimes cutting myself off from research opportunities because I was worried about the reception of my child, like parenthood was something to be ashamed of.

Back at the bus stop, the fight dissipates and the crowded bus pulls onto the thoroughfare. And though it doesn't stop at Kingston Ave as promised, we're able to walk back along Eastern Parkway and arrive safely at my friend's apartment where we're renting a room. It's now getting close to midnight.

The next morning I check out the street where we're staying. Directly opposite, there's a Laundromat and next to that, a community centre. It's not until I'm walking around the neighbourhood that I notice the handwritten sign in the window: Congratulations, Crown Heights. 37 days since the last shooting! The ' 7 ' is a new addition: it's changed daily. 
Maybe I've spent too much time in Australia, listening to news reports that paint the United States as a violent nation, out of control with its gun use, but I'm alarmed. 'Have I brought our child into a war zone?' I ask Scott.

He shrugs, big shoulders that used to play prop. 'We'll be fine.'

I wasn't worried about me or my partner: I was worried about my child, and felt guilty about what I might be exposing him to. The assumption was that my research was jeopardizing my child's safety. And too, there was an uncomfortable awareness that we had the luxury of being able to leave, which kicks at a deeper issue for me: how can anyone write when there's so much political and social work that needs to be done? Yes, writing can be action, and creative work matters - of course it does - but sometimes I'm overwhelmed by the class implications of Virginia Woolf's 'room of one's own' and the privilege of being able to travel for research.

Travel is critical to primary research if the creative work is set in a place unknown to the writer, and the issue with travel and parenting is that travel involves risk: you may well be going to places you've never been and part of that experience is grappling with the unexpected. In my experience it takes time to understand a place enough to convincingly set ninety thousand words there. Obviously this varies depending on the novelist and the project, but I would have been hard-pressed to accomplish my research in less than the six weeks we spent in New York. Ideally I would have stayed longer, with time to draft, but that wasn't in budget.

As my project has emerged, it's turned out that travelling with my family actually provided important experiential data. The novel is now fully drafted (although by no means complete - I've sunk into the rewriting process now) and I know the protagonist is a single mother travelling with her son from Sydney to Brooklyn. Whether these character choices would have transpired if I'd been travelling in different circumstances, it's hard to surmise. However it's turned out that travelling with family was not an added pressure to the business of research: it was the research. I wasn't a single parent by any means but much of the detail in the manuscript about the main parent-child relationship was observed through direct experience - for example, moving with a child through a crowded subway station, the power of a Lego caravan to keep a child occupied, the knock-knock jokes with no punch line, etc. Of course the novel is not about my child and I am not the protagonist, but many details have been gleaned from lived experience.

Sometimes too researching with my child provided interesting ways to connect with the research material. Before our first trip to dumpster dive with the folks from freegan.info, we attended a meeting at the Atrium, 60 Wall Street. It's a privately owned public space: a vast room with a wall of windows to the street outside, whitemarbelled columns that jut upwards and tall palm trees growing inside. Eight or nine of us sat around a table with snacks (dumpstered goldfish crackers and gourmet chocolates).

To understate it, I was apprehensive about turning up with Seattle. I thought his presence would alienate me from the group (after all, who brings their child dumpster 
diving?). I'd considered going alone, but after the bus stop incident I was wary of travelling back to Crown Heights late at night, as dumpster diving tours frequently go well past midnight. The worry here - about how my child would be received - was very real. If I'd been a single parent, without a two-to-one parenting ratio, I would not have brought my child - and this, interestingly, would have meant a much less meaningful research experience.

The meeting ran with a focus on equality - the folks ranged in age from early twenties to early fifties. The person leading proceedings, Janet, was a woman in her late forties or early fifties with piercing blue eyes. She told one of the attendees to keep a watch on her 'so I don't talk too much' and she was serious, not because she was an over-talker but because freegans aim for equality in process, and speakingtime matters. We introduced ourselves, and everyone was given the same amount of time to speak, including my son. There was also a person nominated to watch over the vibe and interrupt if things got heated, though in my experiences with this crew (that night and over the next few weeks) I saw little evidence this was needed. While it may be unconventional to take your child dumpster diving - we didn't get home until well past one in the morning - I was excited he could see decentralised decisionmaking in action. And surprisingly (for me) it seemed the group got a kick out of having a kid there.

More people turned up when the meeting was finished so there were about twenty of us. Some were new to dumpster diving - college students from NYU doing it for a non-fiction class assessment - and others were travellers, looking to lighten the burden on their budgets. The older folks seemed to be the regulars, and there was a mix of ethnicities. I was surprised by this diversity. The ethnographic research I'd come across said that dumpster divers are usually white young men. As I said before, many of the people I came across seemed to be diving out of choice - these were folks who'd made a conscious decision to live with less 'stuff' and more time in their lives. Some of them were probably doing so out of necessity but there didn't seem to be friction within the group about individual motivations.

We were given a run-down of the rules:

Leave any dumpster site cleaner than you find it.

Don't block the sidewalk (while going through garbage isn't illegal because it's deemed to be in the public domain, blocking the sidewalk can get you in trouble with the police).

Everything is shared - take what you need but offer your finds to the group (something in keeping with my experiences dumpster diving in Australia) and don't take anything you won't use (someone else may try diving at the same spot later in the night).

It's important to thoroughly clean anything you find before you eat it - soak it in vinegar, etc. This means there's no eating on site.

I'm surprised Janet would have to articulate this but before the night was finished one young man had a chicken schnitzel dangling from his fingers and started gnawing into it, right on the sidewalk. 
When we kicked off on the trash tour, it was about nine-thirty at night. Seattle was wide-eyed, up on Scott's shoulders. We were moving as part of a herd, wandering up and down Wall Street and back alleys, stopping in front of any shop with a big mound of plastic bags in front. I brought gloves and got straight into it, untying knots, often sifting through bags of employee garbage - plastic bags, empty soda bottles, candy wrappers - without any luck. In New York City, dumpster diving is a misnomer: usually it's just going through bags of garbage lined up on the street.

Then, in front of a bakery, there was a flurry over three bags: 'Here we've got bread rolls. Lots of bread rolls.' Janet was holding a bagel over her head and people flocked in, popping the sesame and multigrain rolls into carry bags.

Another voice from an adjacent pile: 'Yoghurt. Individual tubs - strawberry and mango. Barcodes have been cut out but they don't expire until tomorrow.' Another push. This was the kind of detail I couldn't have imagined - who knew that employees would spend time cutting bar codes out of yoghurt tubs to make them less attractive to dumpster divers? And the general detail of what kinds of foods were thrown away was important as well: even though I'd been dumpster diving back in Australia, dumpster hauls depend entirely on the shops that populate a street.

The biggest scores were from bakeries and supermarkets, but there were often sandwiches in front of the chemist-cum-quick mart Duane Reade and coffee shop Starbucks. I found a bunch of sandwiches from another coffee shop that were still cold but I was hesitant about dumpstered meat so I offered them back to the group and they were snatched up.

The details of travelling with a small child aren't the only ones that have proved important to the novel. In the second chapter, a group of characters go dumpster diving and I've included the physical detail of yoghurt pots with cut-out barcodes, the mass of bread rolls and bagels, Starbucks sandwiches, and supermarket produce (especially the inflated bags of lettuce - too much air is a sign they're probably off). As well, I was inspired by the freegans' decentralised decision-making. As the book is exploring different ways of social organisation and interaction, this example gave me ideas about how characters might interact, even though they aren't in any way connected to the people I met. These are only a few examples of how research has underpinned my creative project - there were hundreds of details and inspirations gleaned while researching that impacted the book. One of the things I love about this creative writing practice is that it demands flexibility - the writer's project will necessarily change because of the research he/she undertakes. The research isn't separate to the creative practice - it is part of it.

And through all of the late night dumpster diving, Seattle was cheering us on, a spontaneous mascot. In retrospect, I wonder if Seattle's presence contributed to the warm environment. Perhaps people were friendly and accommodating because there was an enthusiastic kid perched on his father's shoulders, pointing to garbage bags and yelling out: 'Look in that one, Mum. Look there!'

The worry with experiential research and parenting is that it can take the researcher to dangerous places. If you're writing about squats, they don't spring up in affluent, thriving neighbourhoods. Parts of the South Bronx and East New York weren't places 
I'd feel comfortable visiting at night with or without my child, and each researcher has to strike their own balance between research and personal safety. I take on board this account could well be making a different argument if something horrific had happened during our travels. But still, I think it was important to face into the discomfort of being a researching parent/parenting researcher and attend that freegan meeting with Scott and Seattle in tow - because I'd been policing myself, worried without reason my child wouldn't be welcome, and enforcing a writer-mother duality that wasn't necessary. And while it may be true that as a larger culture we need to rethink the opportunities afforded to writer-parents, it's also true that as a writer I need to make sure I don't alienate myself unnecessarily. 


\section{Research statement}

\section{Research background}

Research is a key component of creative writing, but there are few substantial explorations of how that research occurs, and even fewer that address parenthood within this context. This creative non-fiction account describes the author's experiences in researching a realist, contemporary novel, and how that was influenced by the presence of her child.

\section{Research contribution}

This piece offers a creative non-fiction case study that explores the kinds of research an author might undertake, and how having a child can both present opportunities and challenges to this research process. Because research is usually masked when presenting a unified fictional text, this is particularly relevant for those interested in the craft of fiction. The author also argues that, as a researcher and writer, she needs to question her own drive to compartmentalise research and parenthood.

\section{Research significance}

This piece unpacks how the writer accesses detail that is critical to 'showing' in a creative work and discusses the politics of doing this with small children. By showing how 'showing' works, the author demonstrates the collective layering essential to fiction, offering a map to other writers. In addition, by addressing the question of how mothers of small children can undertake research, she avoids the binary of mother and writer, while also interrogating her own compliance to this hegemonic division. 


\section{Southern Cross University}

\section{Moya Costello}

\section{pressed specimens}

(prose poems from the Southern Cross Plant Science Medicinal Plant Herbarium, Southern Cross University)

\section{Biographical note:}

Moya Costello teaches writing in the School of Arts and Social Sciences, Southern Cross University. She has two collections of short creative prose and two novellas published (Kites in Jakarta, Small ecstasies, The office as a boat and Harriet Chandler). She has critical and creative work in scholarly and literary journals and anthologies. Most recent literary critical works have been published in journal TEXT, including a co-edited special issue Mud Map: Australian women's experimental writing, while most recent short creative works are in Spineless Wonders' anthologies Small wonder, Stoned crows, Out of place and Writing to the edge.

\section{Keywords}

Ekphrasis - Ecocriticism - Prose poems - Southern Cross Plant Science Medicinal Plant Herbarium, Southern Cross University 


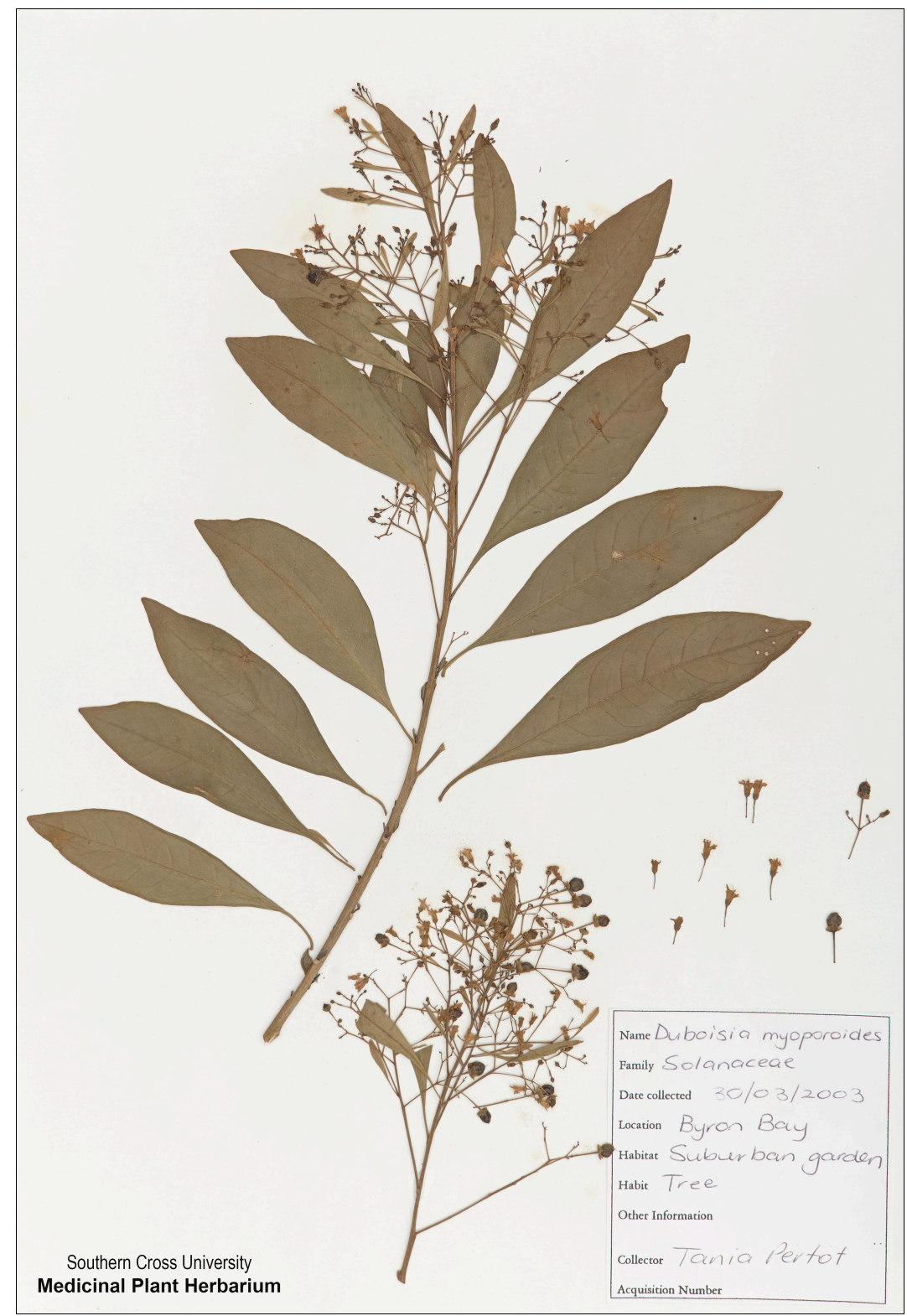

C Southern Cross University 2015 - By Vic Szabo, used with permission

\section{bent askew}

\section{(Duboisia myoporoides family Solanaceae)}

There's a pixie (littleness implied) about the cap with its (tiniest of) fragile spikes. Dare I call it a spike? Possibly a crown, or 'berriness' about that cap. The cap's fringe is a vase base. The small flower pops open often (I imagine) - the Duboisia myoporoides doffs its cap - like a fan, a skirt twirl. The flower dried then to the tiniest straw broom, dilapidated. And the leaf: a rib or an oar of a spine, its 'wavy margin' attesting to not incongruity, being hairless, soft, pale, attenuated, blunt-pointed. A pixie cap left in a flower base: the flower snuck out while the cap snuck in. Duboisia myoporoides is medicinal: those kiddie pixie caps - a spray of pollen drops, dust, spots - for motion sickness (flying, boating: WWII) and gastrointestinal illness. Those spikes bent askew. 


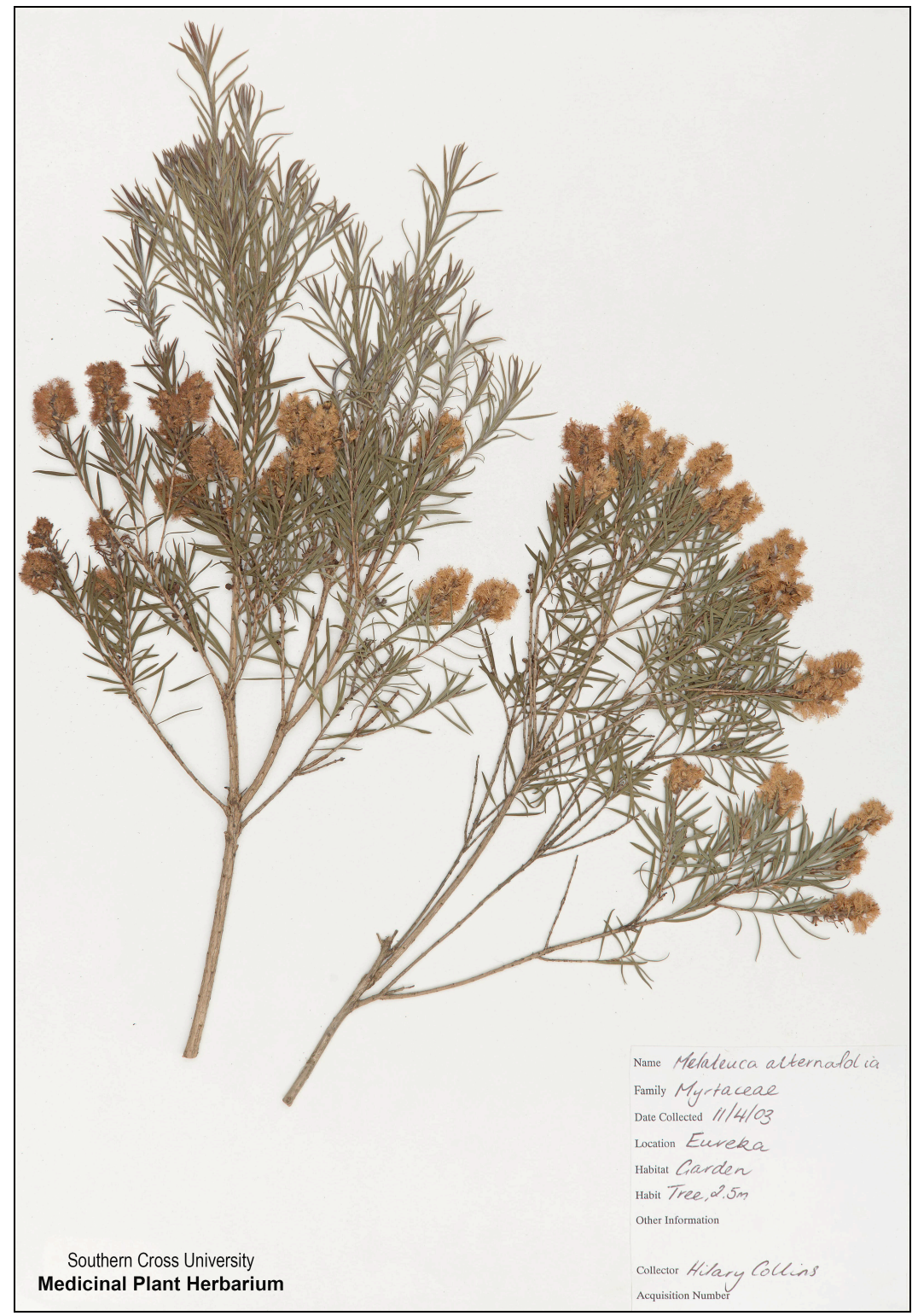

(C) Southern Cross University 2015 - By Vic Szabo, used with permission

\section{not quite}

\section{(Melaleuca alternifolia, family Myrtaceae)}

The dried flower is ... not quite a ball of fuzzy hair (thick-curled). A mid-orange mustard, a yellow-curry rust, a papery fur, a bristled bottle-brush (the angled-bristle type). A pinwheel of the crown's head where the hair whirls, like water down a plug hole - a tough fontanelle, and its sutures. A tangle of crowded seaweed, faded coral, a mess of toasted coconut. Again, a spray of points pin-headed by rounded berry buttons - the tips of those hairs for a breath-to-carry. Leaf spears (think green eels), spotted leaf spears, rosemary-like leaves making up its thin, woody, striated branches - stippled, hooked bark, a subtle prickliness, drying wood you'd discard, avoiding splinters. Not a smooth invitingness. 


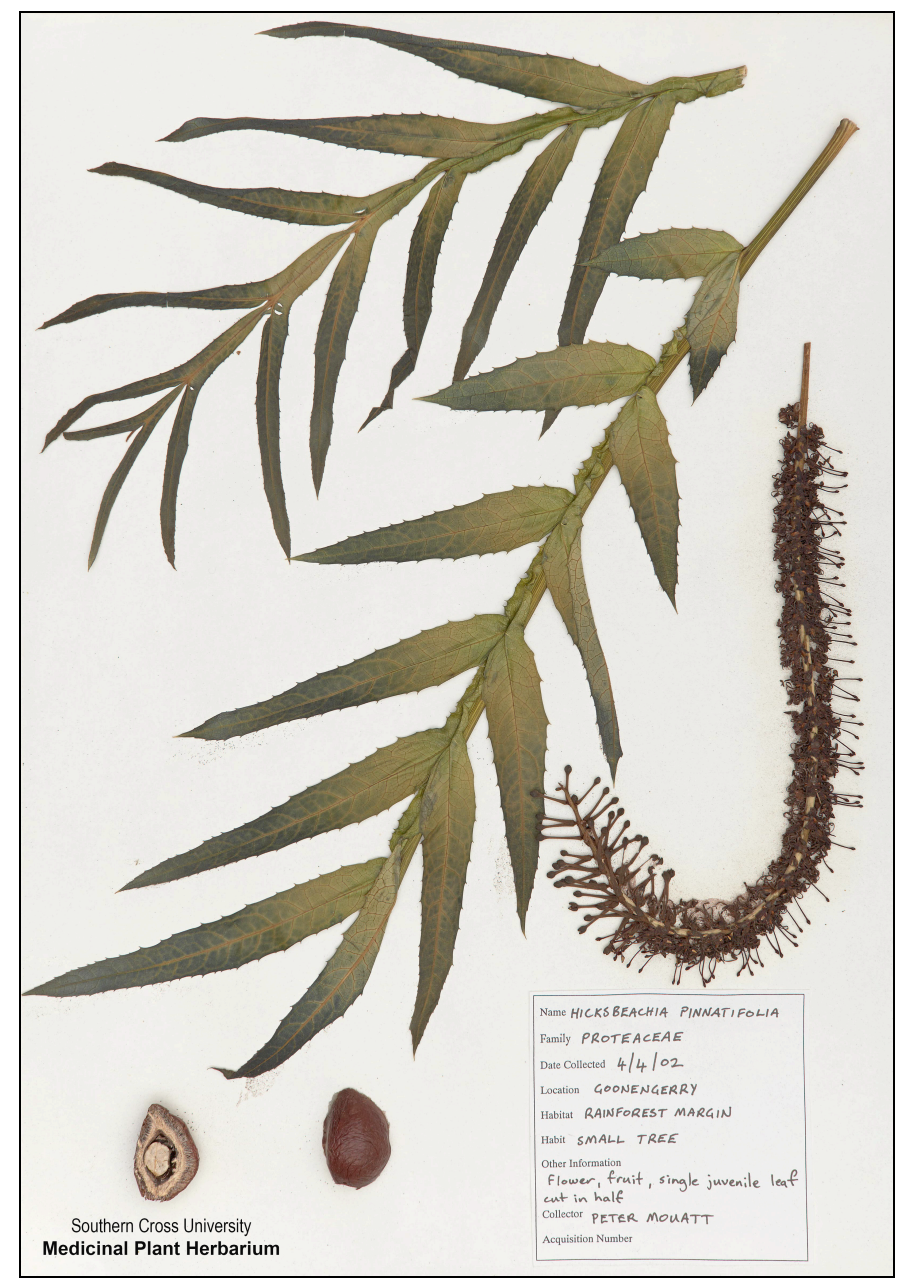

(C) Southern Cross University 2015 - By Vic Szabo, used with permission

\section{all manner of}

\section{(Hicksbeachia pinnatifolia family Proteaceae)}

Thin and fat. Juvenile and middle-aged (spread). Sharp once and now wave point. Tiny hooks, thornlike, to capture, as if evolved from scary to style: pin-pointed manycrests or 'prickly-toothed wing'. Its man(y)-legged/feeted 'very numerous in long'. 'Inflorescence' not 'indeterminate' but, rather, caterpillar compounded. Its length a longship, the 'common axis' many-upright-oared and its hull ruched flounces, dried fruit strips of plum, mango and peach, fig and fire sticks. Those lizard-skinned leaves, and the hairy-headed seed and white almond resting on a leather base: some driedblood raw-meated walnut husk with dust trim at its base whorl smoothed by finger swirl. A secret chocolate heart of layers white and dark. It precious dark-plum redrinsed shell - battle-embellished armour plate ma(i)ssive protection against all manner of imagined battering. A stern hut. A shield ribald with courage. A dome of deep satisfaction. Ferrero Roche chocolates with internal balls doubling contrast. Miniature piñatas. Leaves: sanguine-turmeric-tangerine thin-veined thin. The vessel of the heart, a bopple nut, north of the Bellingen River, NSW, across the border, to Springbrook, Queensland. 


\section{Research statement}

\section{Research background}

Can 'literary poetics' 'claim an engagement' with planetary crises (Potter 2005)? My ecocritical ekphrasis attempts writing inside the more-than-human. Ekphrasis differently articulates 'nonverbal, aestheticised objects' (Haywood 2014: 107). Muecke asks: 'what if ... we wrote ... from our necessary ... convocation with ... non-human things?' (2008: 292). Burns says that the prose poem is, in contrast to other poetic forms, 'more humble ... more subtle. It knows the potential ... of not being too obvious' (1989: 28-9).

\section{Research contribution}

Ekphrasis 'can be thought of as ... [carrying] on with newness', giving 'additional meaning' to the original (Haywood 2014: 110-13). These prose poems are first-time creative writing on dried specimens from the Southern Cross Plant Science Medicinal Plant Herbarium, Southern Cross University. The prose poem - a hybrid, minor form - is not as commonly published as mainstream forms.

\section{Research significance}

This project aims to develop respect for the more-than-human. It supports the Herbarium's scientific work by differently recording. My ecocritical and 'local'-based scholarly work is published in TEXT and Locale; my prose poems in book-length works - Small ecstasies, Harriet Chandler - and anthologies, recently from Spineless Wonders.

\section{Works cited}

Burns, J 1989 'joanne burns: space dust', in D Brooks and B Walker (eds) Poetry and gender: statements and essays in Australian women's poetry and poetics, St Lucia: U Queensland P, 28-9

Haywood, A 2014 'Harlequin Blue and The Picasso experiment', PhD thesis, Southern Cross U

Muecke, S 2008 'Momentum', in N Anderson and K Schlunke (eds) Cultural theory in everyday practice, South Melbourne: Oxford UP, 287-95

Potter, E 2005 'Ecological consciousness in Australian literature: outside the limits of environmental crisis', Hawke Research Institute for Sustainable Societies Working Papers 29, at http://www.unisa.edu.au/hawkeinstitute/publications/downloads/wp29.pdf (accessed January 2012) 


\section{Victoria University}

\section{Enza Gandolfo}

\section{City ghosts}

\section{Biographical note:}

Enza Gandolfo's novel, Swimming (Vanark Press 2009) was shortlisted for the Barbara Jefferis Award in 2010 and the ABC Fiction Award 2008. Her other books include: Inventory: on op shops with Sue Dodd (Vulgar Press 2007), It keeps me sane: women craft wellbeing with Marty Grace (Vulgar Press 2009) and Love and Care: The Glory box tradition of Coptic Women in Australia (Vulgar Press 2011) with Marty Grace. Enza has a $\mathrm{PhD}$ in Creative Writing and is a Senior Lecturer in Creative Writing at Victoria University, Melbourne. She is also the co-editor of TEXT: Journal of Writing and Writing Courses.

\section{Keywords:}

Creative writing - memoir - flâneur - the city 
You arrive at Parliament Station and take the escalators, two sets, the second almost vertical, from Platform 3 up to the exit. The first glimpse of the sky comes, as it often does on your way out of the city loop stations, with relief, as if there is a possibility that while you were underground the world might have disappeared or been altered in some irretrievable way.

It is early autumn, but the sky is grey and the air has a winter chill. You're wearing a jacket, tights and boots; layers of winter clothes. The first Melbournians you see seem to have stepped out of a tourism ad: two young women in flimsy sun dresses and strappy heels drink coke as they wait for the tram, a young skateboarder in a short sleeved surfer t-shirt, shorts and thongs flies around a gaggle of school girls their checked uniforms hitched up with belts. Blonde and tanned, they belong in the Australia of the popular imagination with its long hot summers, its sand and surf; an Australia, where you and your family have never belonged. But you smile as you walk because it's them and not you that look out of place on this cold Melbourne street, where the peak hour rush is a mix of races and ethnicities. Where the sun sets, and darkness hovers.

You have organised to meet an ex-colleague for dinner and a drink in café in Gertrude Street, where you sometimes had lunch during the 6 months you worked together. The café, a couple of blocks from your old workplace - a not-for-profit organization that was housed in an old, poorly maintained terrace - was where you built your friendship, where you came to know each other, where you critiqued the organisation and its management, in an easy camaraderie born out of shared left wing leanings. The organisation has recently lost its government funding and no longer exists.

But you're early on purpose, to walk. All day you've been sitting at a desk and this walk is your reward. No computer. No notebook and pen. No room full of books. No notice board pinned with reminder notes listing deadlines and obligations. No student work waiting to be read and marked. The mobile turned off.

Evening walking is in your blood. Your mother often talks about the pleasures of the daily passeggiata in that other, pre-migration life. A call from a friend or a cousin, a quick change of shoes, a coat thrown over a housedress, the excuse - the need for a ball of cotton or yarn, or buttons for the final touch on a dress - the linking of arms, the joyful banter as they walked familiar streets, stopped to talk or gossip with friends and acquaintances. After a long day indoors, the craving to be out in the world. Or did you inherit this desire from Virginia Woolf, whose writing you have loved since adolescence, who set out in London on an evening not unlike this one to buy a pencil. As you walk you hear her words: As we step out of the house on a fine evening... we shed the self our friends know us by and become part of that vast republican army of anonymous trampers ... Virginia longed for anonymity, your mother for friendly recognition, you long to escape, relief, but with every step, memories unravel.

From the station you head towards Victoria Parade and the Carlton Gardens come into view; the trees - oaks, cedars, elms and the Moreton Bay Figs. When you were an Arts student at Melbourne University, in the late 70s, on summer afternoons, when the sun was scorching, too lazy to go to classes and too lethargic to head home, you lay for hours under those trees. The large patches of shade, the sweeping lawns (no water 
restrictions in the 1970s), and the fountain, water sprouting from its three tiers, transformed the city garden into an oasis. The Royal Exhibition Building, with its pinkish blush, then like now, was regal, but yet you, with your socialist, antiauthoritarian views, were drawn to it and you came here with books, with friends, with lovers.

The Melbourne traffic is building. Inside their cars, drivers are all bristle and spike, itching for a fight; unable to resist a man in a red Honda jerks out of his lane, ahead of him drivers close up gaps and refuse to let him in. There are shouting, horns blowing - the man in the Honda raises a fist out of the car window into the air.

In your childhood you made numerous excursions down this stretch of road by car to visit your mother's sister who lived in Abbotsford or to go to the Victoria Market where your parents shopped for vegetables and meat at least once a fortnight. Before the Westgate Bridge was built, Victoria Street (Victoria Parade between Spring and Hoddle Streets) was the main road linking the west of the city to the east. So most of your trips across the city, unless you could convince your father to take the punt, meant driving down Victoria Street.

Your father in his two-toned green Holden and later his white Valiant Pacer, was an aggressive driver, easily offended. He'd blaspheme, speed, swerve, cut off other drivers with the least provocation. Your mother's pleas that he slow down, that he remember he had children in the car, that it wasn't God's fault, did no good, if anything it fueled his anger, and he became even more reckless. In the back seat, you and your brother held on to your breaths and your seats - no seat belts in those days as your small bodies swung from side to side.

By the time you arrived at Zia's house, your brother was car sick, your heart was thumping.

Zia's house was a single fronted cottage in a narrow street. From her front veranda, you could smell the brewery and watch the men come off their shifts in their stubby shorts and blue sweat-stained singlets; they wound their way from the back door of the factory to the front door of the pub.

'Do you think working in the brewery puts them off their beer,' you asked Zia's next door neighbor, Shirl, a widow, who was often sitting on the veranda smoking cigarettes. Shirl had bleached blonde hair that she teased into a beehive; it sat like a leaning tower over her head.

'They're a pack of drunks. If you let them, they would swim in the stuff,' she said and you noticed that her front teeth were yellow and cracked.

'She's as mad as a cut snake,' said Lucia, your oldest cousin; she had her own beehive and cigarettes that she kept hidden under the trough in the laundry.

You were only eight or nine and did not know about clichés. You had no trouble imagining pools of beer and angry snakes.

Zia's house had a long corridor that ended at the dining room where the adults sat around a table and drank weak coffee. 
'She doesn't know how to make coffee,' your father complained, 'it's like dirty water.'

The cousins, sometimes up to a dozen, would head out to the concrete backyard or through the gate in the fence to the laneway where you played games when you were very young, where you hung out and made fun of your parents when you were adolescents.

You loved Zia - she was your mother's half sister, 20 years her senior. When the two sisters were together a look, a wink, could set them off into fits of laughter. Laughter that could go for hours, that could infect a whole room, that could drive the men crazy.

You loved her house. Three women - your aunt and her two daughters - lived there together and you envied them. Even though your uncle's death of cancer in his 40s was tragic, you thought of them as lucky. No men. You imagined they lived a utopian life.

On the way home, on warm days, your father would stop the car at the gelateria at the North Melbourne end of Victoria Street; one of the first gelaterias in Melbourne. The man behind the counter took a small scoop from each flavor - orange, lime, chocolate, strawberry and your favorite - lemon - and built mountainous icy peaks. The whole family gathered around a table outside the café. Fingers sticky and sweet, nose freezes and laughter. You remember stains on new clothes and your father's benevolence turning into rage.

Your father's rage - here it comes again - in your memories he is in a constant state of rage, at other motorists, at cars, at the dripping tap, at the dinner, and of course at your mother, your brother and you. He's dead now and your brother says, you exaggerate.

The stroll has turned into a stride, and you have to bring myself to a full stop before you can slow down. You have arrived in front of St Vincent's Private Hospital with its solemn grey black exterior. Originally founded by the Sisters of Charity in 1893 to service the poor and disadvantaged living in and around Fitzroy, the hospital (now merged with the Mercy) continues to be run and operated by the Catholic Church. To you it has become a symbol of privilege now, your father's access to it only afforded by his ability to pay a hefty private health cover.

It was here on the footpath outside this hospital that your father, an old man by then, due for one of his regular blood transfusions almost collapsed. Your husband, unable to find parking in the heavy midday traffic, dropped you off in front of the hospital so that your father weak and frail would not have far to walk. You and your mother took one arm each but his legs would not work, his knees buckled. You could not hold him. You scanned the street for help. Most people skirted around you. And then a man in blue jeans and t-shirt, his arms and neck a canvas of blue, black and red tattoos dropped the shopping bag he was carrying and slipped his body behind your father's so that he became a frame, a chair, on which your father could sit.

'I thought he was going to snatch my bag,' your mother said later, 'he looked so rough.' 
Instead, he'd helped steady your father, to get him into the hospital and a wheelchair 'Thank-you,' your mother called out after him.

There was a band of tattooed fathers in your neighbourhood when you were a child. They worked in factories and building sites during the day and in the evenings they kicked footballs or played cricket with their kids on the street. There was laughter, but also plenty of yelling and swearing, and occasionally a fight or two, usually between the kids, sometimes between the men. You stood behind the gate that your father insisted on keeping shut so you and your brother would not run out on the road and longed for an Australian father who drank beer and not wine, whose arms were covered in tattoos.

Some of those men sneered at your father and called him a 'wog'. Your father somehow managed, at least when you were around, to pretend he hadn't heard or understood and to keep walking. The wives of these same men asked your mother to knit them woollen suits, and cardigans, but they never invited her over for afternoon tea. And their children did not have wogs for friends unless they did and then only one, just you, because you're not like them, not really a wog at all.

Your father's near collapse was only one of a series of events attached to your memory of his death at St Vincent's and your work at the research centre. As you walk to cross Brunswick Street, as you leave the hospital behind, the weight of those months, clings to you, and the associated anxiety, as if no time has passed between then and now, as if you were arriving to visit your father, who had not died, who you would find-cantankerous and demanding.

One morning, back then, he had laid out his shirt on the bed placed all of his belongings in the centre and then tied it into a swag.

'I want to go home,' he said when you arrived.

'Well, you can't.' This to and fro went on for several minutes; you could hear his obstinacy in your voice.

'I have to go to work,' you said and then you left.

Your father died days later. Earlier than his doctor had predicted. Partly you think because he no longer could control his life or his family's. You remember watching him take his last breaths, your father who had been dying for some 40 years, and you remember feeling both relief and disbelief - you had convinced yourself he would outlive you all.

As you turn the corner onto Smith Street, a father and son walk past eating ice-creams and you watch the way the son mimics the father. Walking fast to keep up, the boy is a small replica of the man, short pants, tee-shirt and thongs. He seems intent on becoming the father and you envy him his admiration. Did you ever want to be your father? Walk alongside him? Or in his footsteps? Or was your relationship always as problematic as you remember it? Whenever your brother and you argue, and he wants to get the better of you, he says, 'You're just like Dad, you know.'

Your father was never at home in the streets of this city and on the rare times you ventured into Melbourne with him, he was always a little lost. A peasant Sicilian from 
a village in the hills where every cobblestone was familiar, every passerby related, he only ventured into Melbourne out of necessity - in the end a place for hospitals and doctors' visits, it would have bought him little joy. If he had been a young man now, and not in the $50 \mathrm{~s}$ and $60 \mathrm{~s}$, when Italians were wogs and dagos, would he have grown more at home here, have come to feel part of it, to find joy in it, would have chosen to take an afternoon passeggiata through its streets?

It is almost 6.30 and you see your friend in the distance, making her way into Gertrude Street. She is riding a bike. You can't ride, you never learnt - faulty balance, you prefer to have both feet on the ground. When your friend told you, her father was a postman in Greece before he migrated, you said, 'So your love of cycling is inherited'. Your friend laughed. 'Yes. First, he had a donkey, and then a bike and then a scooter.' She had a better relationship with her father than you with yours but who can say why. 


\section{Research statement}

\section{Research background}

City ghosts is part of a series of short but interconnected autobiographical pieces on the relationship between women and the city as encountered through walking. This series is inspired by writers who were walkers, such as Walter Benjamin, Charles Baudelaire and Virginia Woolf, and women writers who challenged masculine notions of flâneur such as Woolf, Doris Lessing and Djuna Barnes. This piece is also concerned with the way people are excluded from the city, or marginalized within it, on the basis of class and ethnicity.

\section{Research contribution}

The philosopher Adriana Caverero argues that through the narration of our stories we might come to see who we are; this piece asks: who are we in this place? Written in the second person, it works to actively position the reader on the streets of Melbourne, in an exploration, not only of, the protagonist's identity and sense of self, but of the identity of the city. Melbourne has a diverse population, the city is in a constant state of change. This piece contributes to writing and storytelling that aims to capture that diversity.

\section{Research significance}

The series of which this piece is a part began with a blog (at http://femaleflaneur.wordpress.com) (no longer active) funded by a City of Melbourne Arts Grant - to open up discussion about the nature of contemporary women's relationship to the city, and the relationship between walking, memory and placemaking. The project has expanded in different directions, including several short pieces and a novel (in progress). It is part of the author's body of creative work as a writer and academic that explores issues of class, gender and ethnicity especially as they relate to the city.

\section{Works cited}

Caverero, A 2000 Relating narratives: storytelling and selfhood, PA Kottman (trans), London: Routledge

Woolf, V 2008 'Street haunting: a London adventure' in D Bradshaw (ed) Virginia Woolf: selected essays, Oxford and New York: Oxford University Press, 177-87 


\section{University of the Sunshine Coast}

\section{Thomas Hamlyn-Harris}

\section{Leonard's gambit}

\section{Biographical note:}

Thomas Hamlyn-Harris is a Queensland-based illustrator and writer currently studying Creative Writing at the University of the Sunshine Coast. His published works include educational games, puzzles and activities, children's songs and pop-up books.

Keywords:

Creative writing - multimodality - hybrid text - graphic novel - illustration 


\section{LEONARD'S CAMBIT

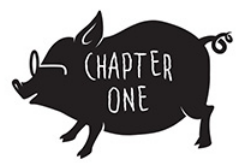

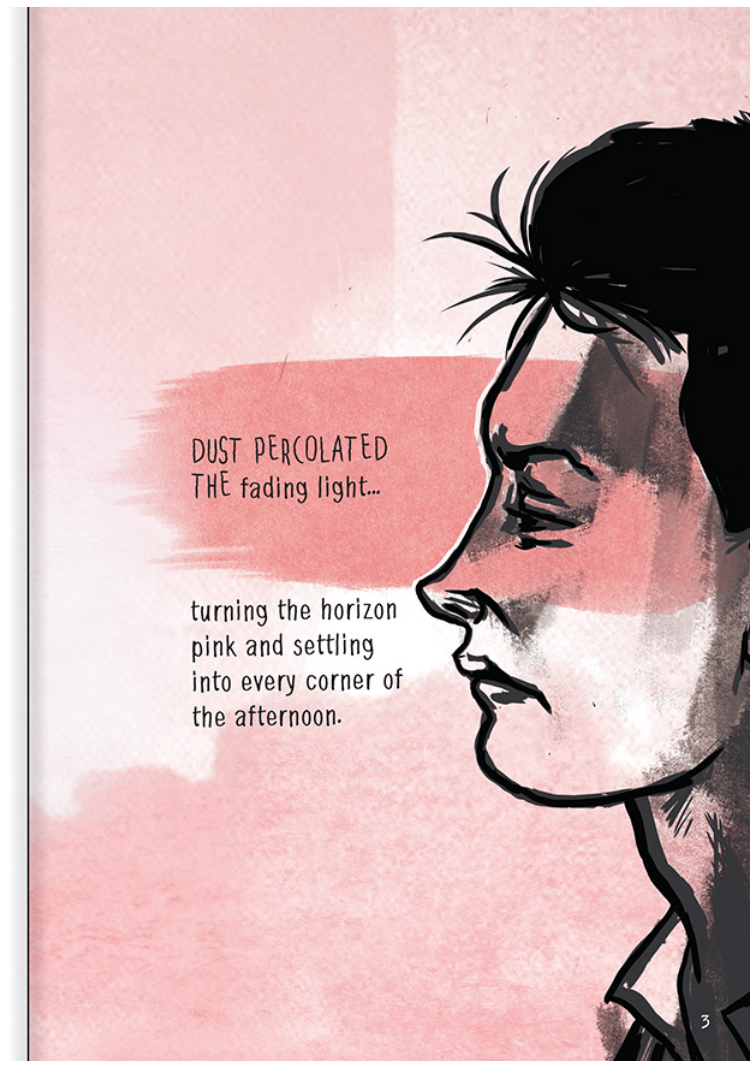

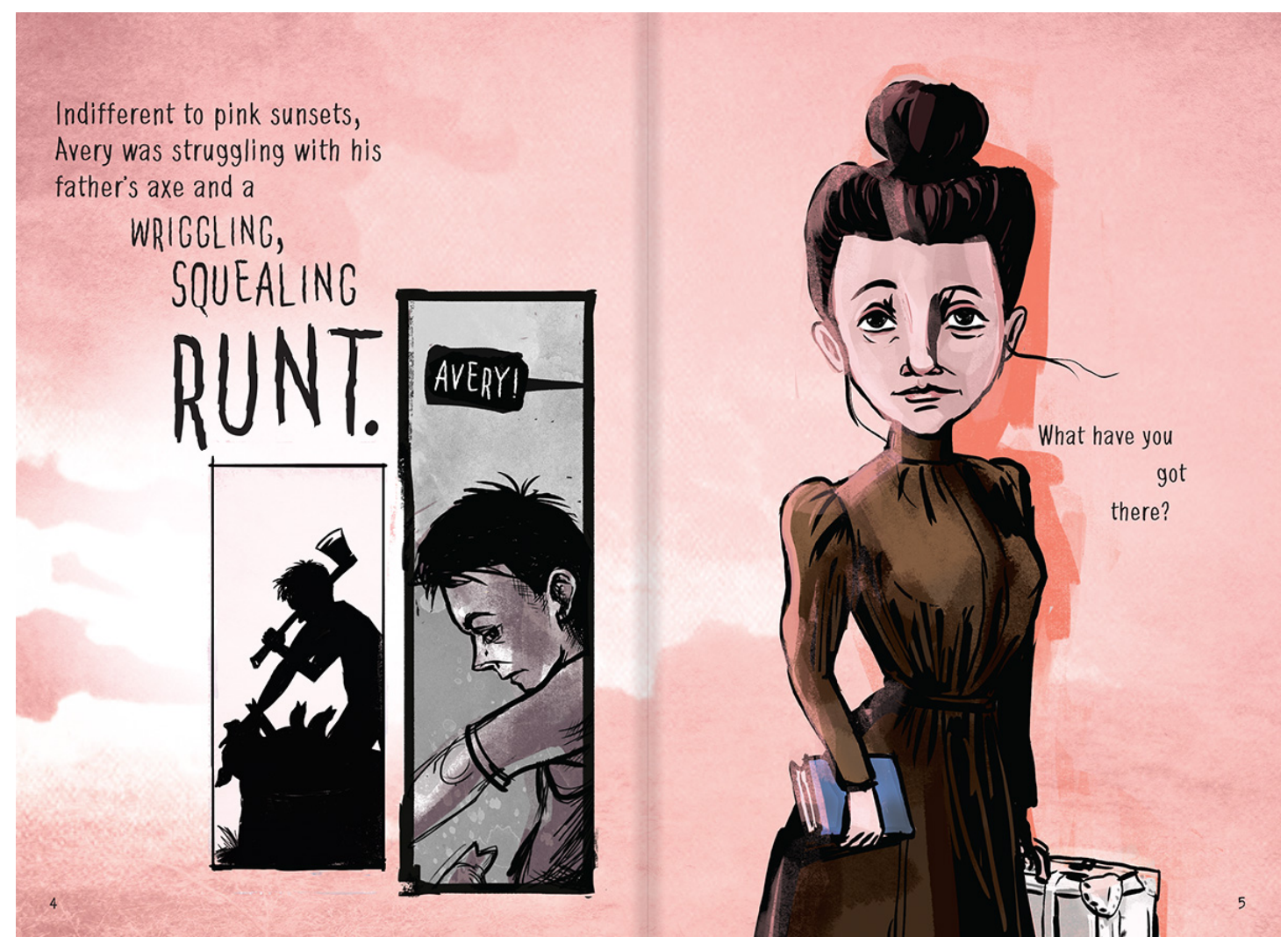



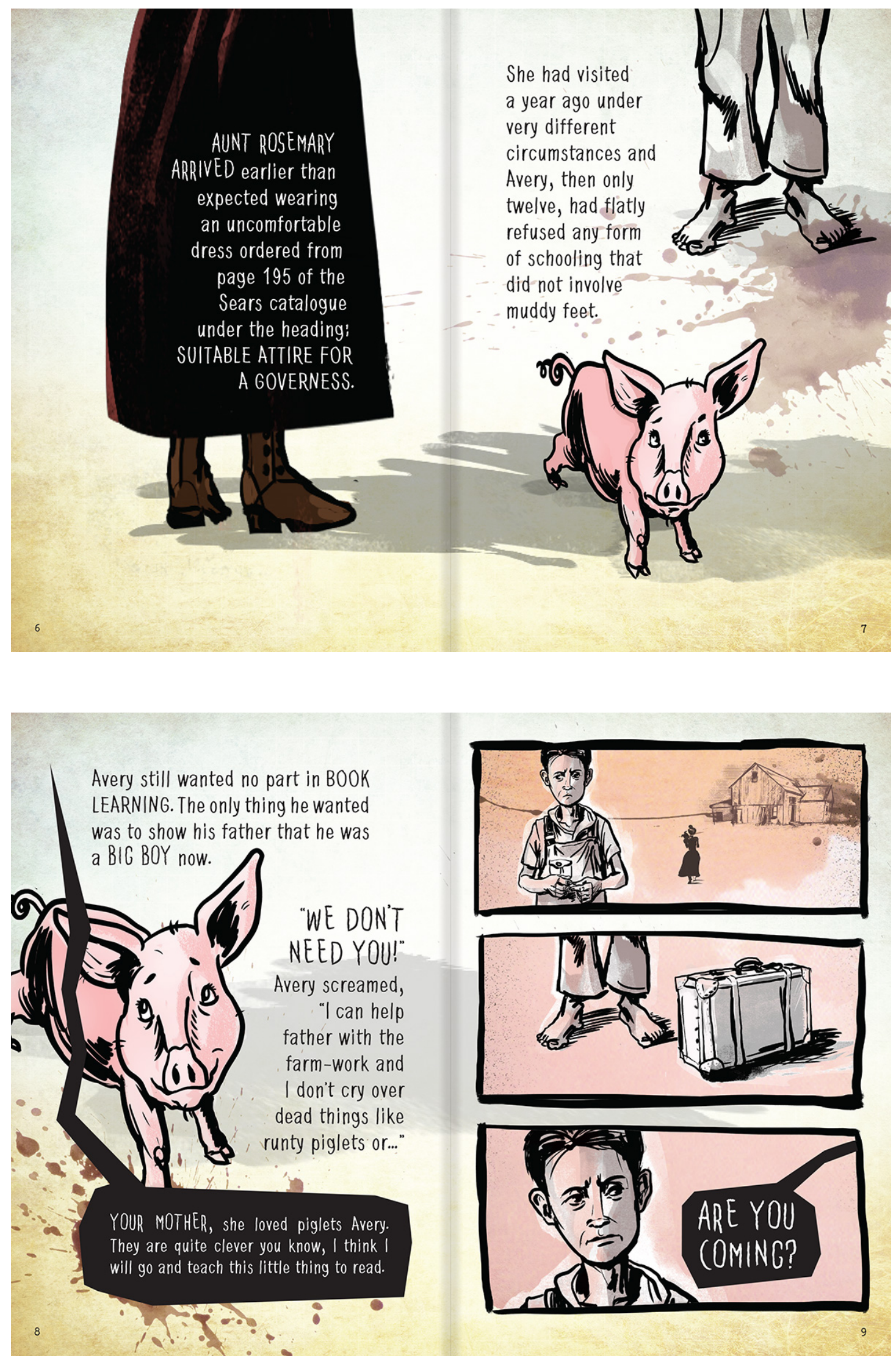

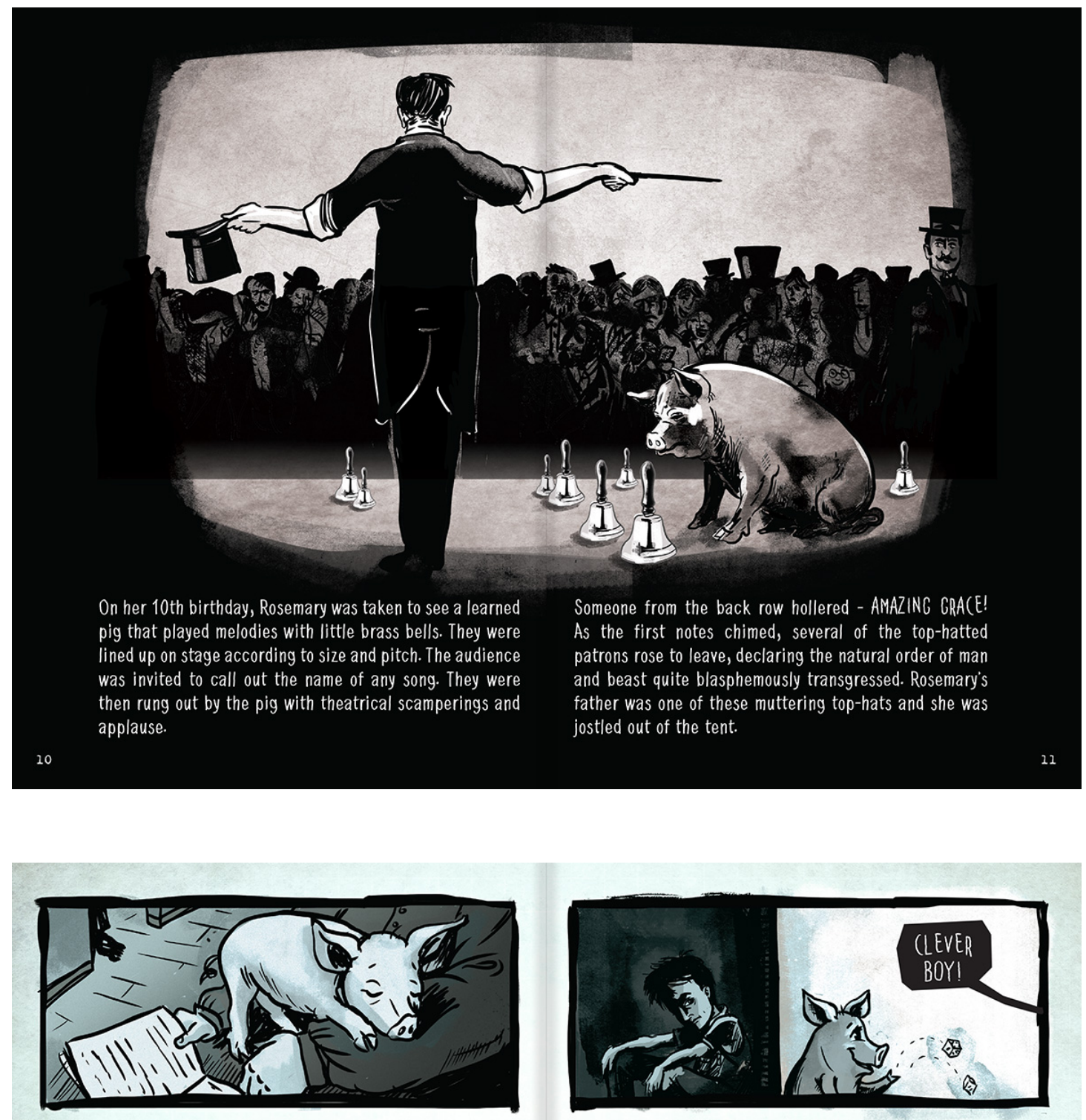

AUNT ROSEMARY'S NEW student was named LEONARD and was allowed on the back verandah. He was surprisingly attentive in most of his classes and showed an amazing aptitude for games. Aunt Rosemary taught him how to play Noughts and Crosses.
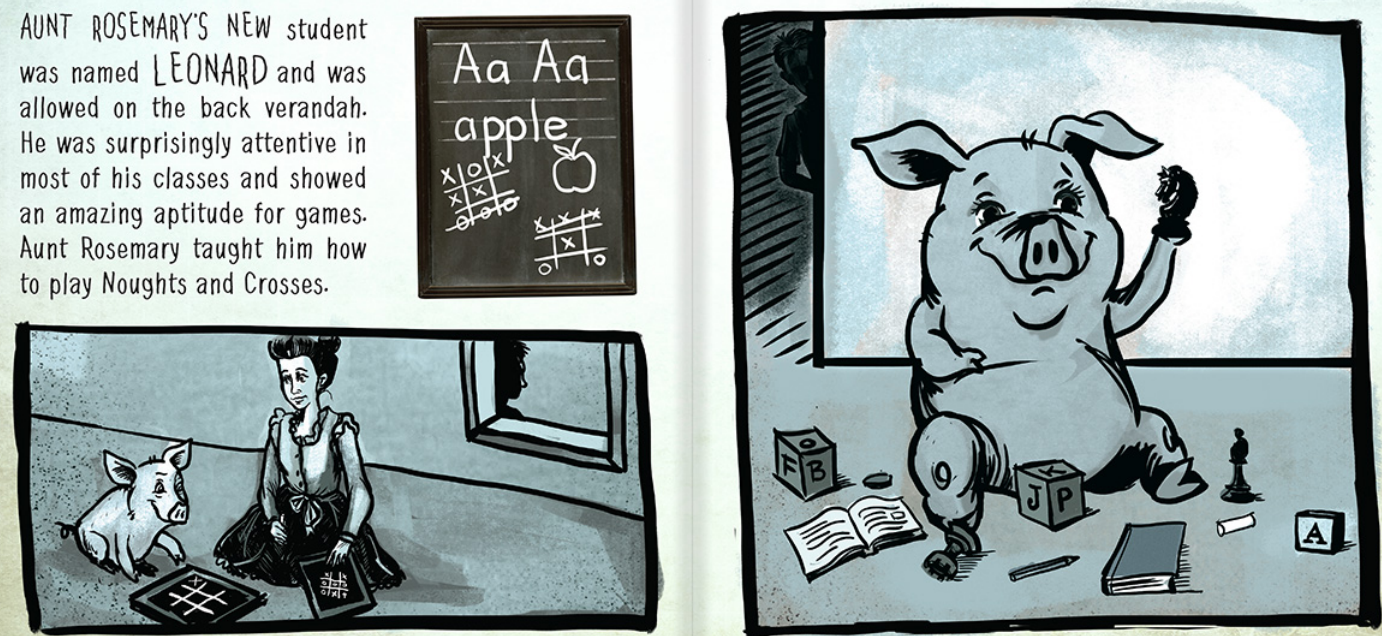


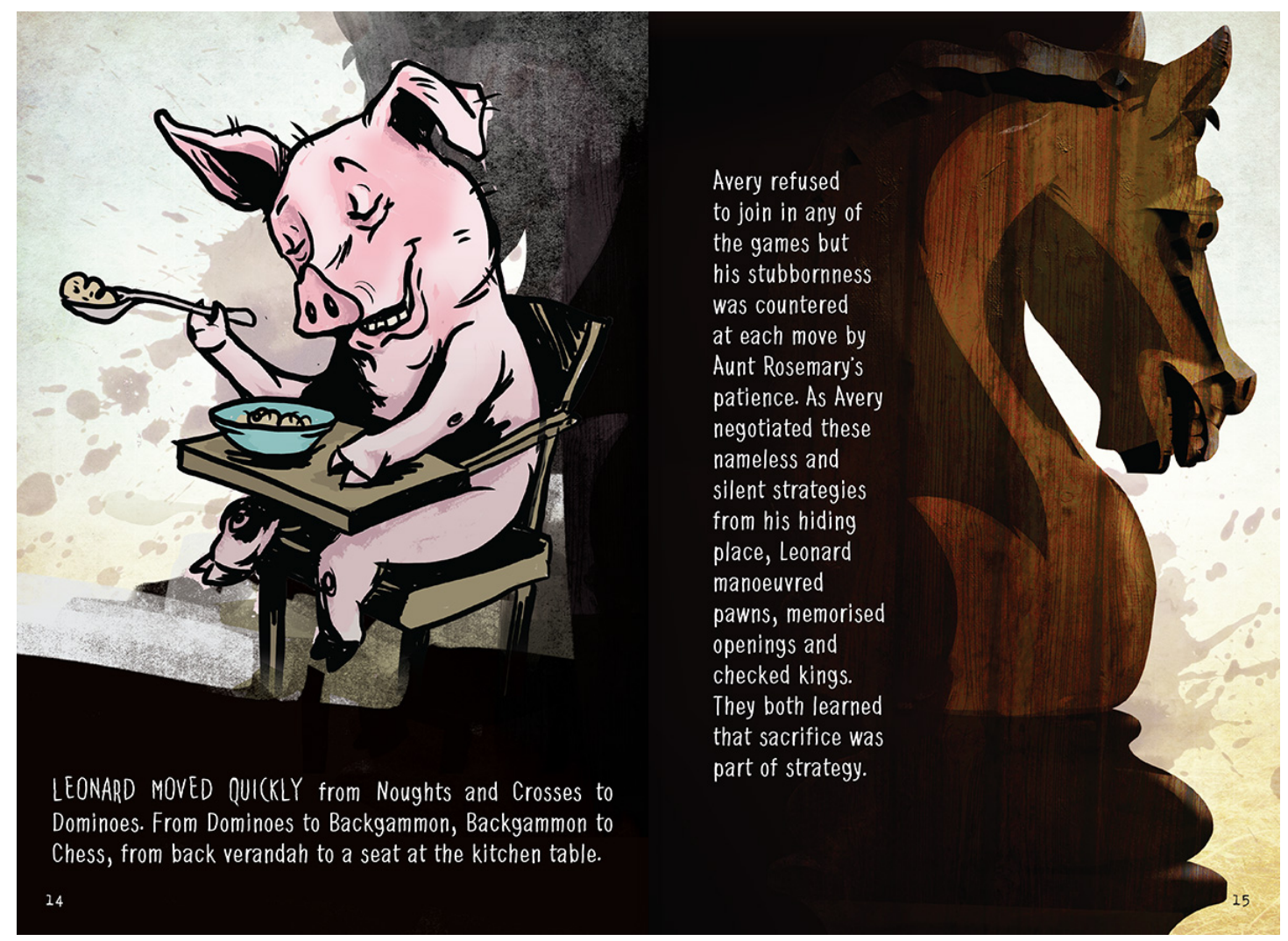

TEXT Special Issue 30: Creative Writing as Research IV, October 2015

eds Nigel Krauth, Donna Lee Brien, Ross Watkins, Anthony Lawrence, Dallas Baker and Moya Costello 


\section{Research statement}

\section{Research background}

Many contemporary authors and illustrators recognise that the interplay of modes text, image, typography, design and other semiotic resources - can be manipulated into a hybrid style of narrative that is more than the sum of its parts. This hybrid approach undermines the view of text as the primary conveyer of meaning, and rather than coexisting, modes interact to breed an entirely new creature (Sadokierski 2010).

\section{Research contribution}

Even in picture books, words have historically had the upper hand and images were generally expected to behave themselves: to represent or illustrate the meaning of the text. This research aims to embody 'the creative conflict between words and images' (Crew 2015) and reflect a cultural shift towards multimodal communication and literacy.

\section{Research significance}

Books are more than the storage mechanism and organising principle for a collection of words and images. Books scaffold meaning in unique ways and their physical appearance - paper stock, font, colour, graphic elements and so on - contributes to the reader's experience and emotional connection to books as objects. Foregrounding the material construction of the book (Schiff 1998) (which is difficult to convey in its current digital format) reveals how sensory properties can act as modes, contributing to meaning rather than just the experience of reading. This work has been selected for publication in a quality peer-refereed journal of creative writing.

\section{Works cited}

Crew, G 2015 Personal communication, July

Sadokierski, Z 2010 'Visual writing: a critique of graphic devices in hybrid novels, from a visual communication design perspective', PhD diss., University of Technology Sydney

Schiff, KL 1998 'The look of the book: visual elements in the experience of reading from Tristram Shandy to contemporary artists' books', PhD diss., University of Pennsylvania 


\title{
Southern Cross University
}

\author{
Ashley Haywood
}

\section{Harlequin Blue; or, A place like Paris and a new brain map}

- after Pablo Picasso's painting Autoportrait, December 1901, Paris

\section{Biographical note:}

Ashley Haywood recently completed her creative research $\mathrm{PhD}$ thesis Harlequin Blue and The Picasso experiment with Southern Cross University. She has had writing published in journals and anthologies, and in some cases performed, in Australia and overseas. Most recently, her prose poetry appears in Spineless Wonders' anthology Out of place (2015) in print and video artwork. Ashley's creative writing and research usually involves art/ists and often draws upon her background in the biological sciences.

\section{Keywords:}

Creative Writing - Experimental writing - Pablo Picasso - Biosemiotics - Complexity Creativity 
We have met before, and you call me Harlequin. We've met in every instant: the lost beginnings, worlds out-of-time. And you'll ask me, what is love in this place?

Listen for the jingling and tinkering at the door, which is not really a door in this story, or a stage, but a cobblestone street in the evernight.

This instant is almost in time-Floating Man is here, the street-lamps are lighting.

What is love in this place? Let me tell you a story.

Slow and heavy in a pair of oversized, wet boots, a floating man shifts one foot after the other beneath a thick, charcoal woollen coat. It hangs like bedding from the neck down, over a pocket-filled chest soiled with soot and the all-night. Beware a coatshuffle so cumbersome, thicker than memory and flesh.

Look at his mouth. Babe-naked and clean as a worm.

Wet and warm, the Floating Man's lips part open to smoke in the cold with a loosely rolled cigarette. The match burns down to his nail as he exhales over his upturned collar - just now (wait, there, pause) he could be the eternal lover, suspended, tightrope high above nicotine alleys. Is he daring the whole city to topple, the evernight to fall?

We look up with him, we look up to a fading bombazine, starless and tattered. Its holey warp and worsted weft hangs over cobbled corners, mourning space at the dead ends and double-backs, spooling lost-and-found thread into every hidden crack.

Darkness has become a toothless thing with thimble eyes, a thousand blinking eyes, watching from under hitched-up cloth, making lovers of long shadows and stone nooks. The darkness grows fat. Smacking its jaws around a gummy face, the darkness says, Come home, my lovely, come home to the dark blue sea. ${ }^{1}$

With every pause, every step, Floating Man bends toward abandoned things and things not whole - half-empty bottles and sodden underwear, fresh cigarette butts dropped after having kissed multiple strangers - things this city has yet to gather into its folds, what is not yet pulp in its grey snow.

A street-lamp sputters, flickers its halo, detaching passing limbs from the evernight (muses scatter to their nests that once were neat) and a sign overhead reads (Rue de la) (Rue de la) Pêche. ${ }^{2}$

Floating Man dips his head beneath pegged bed-sheets, hoisted window-to-window, hanging heavy over the alley, rope after rope. Beating windward, his waterline bobs under and between the damp, life-stained linen.

There is no sea here, stop thinking of the sea, thinks Floating Man. But what if there were a sea to find downstream, in the beneath-stream of the river-running fissure, beneath clay and silt in the below of the below?

The alley opens onto a new avenue. A canal is to the east, a somatosensory gyrus to the west. The trees are bare, their trunks are bald. Street-lamps pop light over his synaptic footsteps. 
Floating Man trawls with another cigarette, glowing over the ruins of split wood and corrugated tin from another time, another shipwreck.

Look again, Floating Man, and let The City see itself in water. ${ }^{3}$

Behind Floating Man the street-lamps are almost out, and his footprints begin to tell a different story, one as slippery as the gutters: there once was a floating man who crossed an ocean.

Behind him the sheets have set sail in the alley, and the alley is almost lost to itself as like a horizon.

Floating Man doesn't look back, but looks ahead with the street-lamps that are still waking as he walks, lighting stone walls and locked wooden doors, iron knockers rusted and fused, and there is a heavy taste in the air of people who having massed and eaten are now centuries gone. On his tongue is the salt of men and women and muses. He stops, drops his cigarette. Are the doors unlocking from their latches? His coat is wet, his pockets deep, he fingers polished bone.

Clap-clack like a bird-call.

Floating Man is turning his head - Yes, yes! Look!

See what lives in the dark!

His Andalusian nose breaks frame, turning clockwise, eyelids-eyelids half-open. There, in the dark, is a thing, half-whole and feasting and half-full, its scent twisting the lamps go out!

The thing arches back on itself, and crawls out from his sharp nasal passage as a flayed homunculus with a mouth as wide-as-wide throat open and gasping, laughing in the dark, eating itself feet-first until it vomits. ${ }^{4}$

Floating Man's brain remaps.

A new boulevard shows off with a hundred new lights and a round-a-bout with spokewheel streets radiating in every direction. Floating Man walks on, and he does not look back, as doors and stonewalls are remade in the dark, opening when he has gone. Gas goes pap-pap and the lamps that sap methane from the Undercity shine blue on his fresh footprints in the snow. ${ }^{5}$

\section{Endnotes}

1. We drift into the velvety mould behind the eye, the warm fuzz behind the eye, and go further into its humming black, further and further into the starry-split between skin and No-place.

Down in the below of the below, darkness is folding space into a labyrinth of ends, barb-wired with cat-piss. Travellers in the under-darkness scratch pit-tap directions in stone like love letters. On these roads, we sleepwalk tirelessly, hooked on endlessness, spinning our own inferno circuitry all the way back into the arms of darkness, the great-grandmother of darkness waiting at the kitchen door.

She sucks on our eyes, mouthfuls of fire. Spits out white-spots to make us laugh.

We laugh, and shut-up our eyes. 
We find hallelujahs in a grain of sand while the darkness catnaps. We cross its glassy peaks like water, as water moves through the infinity of sand. (Muses sing out: Hoorah! Ceci c'est ne pas la terre!) And we lay back like giants curved over a new moon.

Beneath its frozen waters, we know life is on the move, and we listen to sonic clicks deep down in the deep, cold abyss of the moon.

2. Muses come and go, blimp-lipped from the fissure. Some still caught on the lines, slurring words behind rusty tackle and half-chewed once-were things. They cough-up handfuls of silt from their gullets and sinkers clink when they hand out guarantees for the scent of things to come yesterday.

They are not old or young, but in a past, on repeat, so they come and go from the river-fissure, flaunting their dead limbs and epitaphs with pearly grey runners beneath their skin.

Muses carry the river on them, searching for home in sandy pockets. They are a thousand mouths awaiting a shipwreck.

3. Floating Man looks over the side of the boat, deep into the ocean's belly, where whale carcasses tumble down chasms like coins, and his less than mouthful-face is speechless.

We pick up Poulpe [Poulpe is Gora in the form of an octopus] who speaks fluent silt and sulphur and eggs. She calms the ocean into steps before nightfall. And, as we climb the sixfloor swells, we can see through the windows of sunken cities.

Limpid attics hold us - teasing, tipping — before plunging the boat into their lightless basements. As we rise, bioluminescent lamps flicker on every other floor. The lives of fish are exhausting: parties gather in kitchens, singing round-robins with the darkness, while others plot murder behind closed doors, but all are smoking up their living rooms with ravaged flesh.

At the top of the stairwell, we meet glittering rooftops, starry rooftops.

We swoop, we fly, we fall down ocean floors.

Behind us, Floating Man watches hydrangeas bloom, in the bluer-blue, a red of doorways. Their floating heads follow the boat like a funeral procession. [Gora throws two coins on the bar for one last drink.]

Behind us, there are black fins, so graceful, so steadily they thread back and forth across the face of the waterworld, tending all the flowers, weaving flowers in her watery hair.

Pouple looks into the face of that waterworld and falls in love with the unbearableness of love. Without looking back, she dives limbs-first, deep into goodbye, goodbye blue.

4. A sea-monster is lurking, a-lurking in the dark.

5. Listen with your eyes, then your hands. Let sound loiter between hairs-on-end which are each their own frequency and swan-song. Practice until you forget your bones, and your eyes finally break free to make love with their optic nerves, twisting and feeding on the rest of you until they self-cannibalise. In this city, there is no curtain call, there will never be an applause. Just shoes on a bridge.

Leap! 


\section{Research statement}

\section{Research background}

How to write like painting? This question led to investigating creativity in terms of biosemiotics and complexity theory, and an understanding of 'mind' as different to 'idea'. Biosemiotics describes life, from molecule to song, as a web of complex nonlinear evolutionary feedback systems of sign relations (Sebeok and UmikerSebeok 1992, Wheeler 2011). Contemporary bio/semiotics is in its youth, especially in its relations with, and applications to, other disciplines and/or fields of practice (Kalevi and Velmezova 2014).

\section{Research contribution}

Harlequin Blue is an experimental prose-poetry-play work, set in a city-as-brain, in a suspended instant of time. Harlequin's narrative follows the action of Floating Man's mind internalising newness. Excerpts have been arranged here to illustrate a condensed version of the whole. The writing embarks within Picasso's Blue Period (1901-04) paintings to pursue possibility in 'non-knowing', to capture the 'wholeness' of a monadic instant, as a painter might do with paint. The writing engages with a cultural momentum - growth dependent on metaphor, or imitation-for-newness - which pushes the receptive 'mind' toward internalising newness, consequently disturbing 'wholeness' and knowing. Harlequin Blue is a story and investigation of this (its own) emergent and necessarily disturbing (for growth) process.

\section{Research significance}

Harlequin Blue and The Picasso Experiment is a recently completed creative research $\mathrm{PhD}$ thesis. Excerpts from Harlequin Blue (creative component) have been performed in Paris, France.

\section{Works cited}

Kull, K and E Velmezova 2014 'What is the main challenge for contemporary semiotics?' Sign Systems Studies 42 (4): 530-48

Sebeok, TA and J Umiker-Sebeok (eds) 1992 Biosemiotics: the semiotic web Berlin: Mouton de Gruyter Wheeler, W (ed) 2011 Biosemiotics: nature/culture/science/semiosis Open Humanities Press, at http://www.livingbooksaboutlife.org/books/Biosemiotics (accessed 31 March 2015) 


\section{Griffith University}

\section{Nigel Krauth}

\section{By the fingernails}

Biographical note:

Professor Nigel Krauth is head of the writing program at Griffith University, Gold Coast, Australia. He has published four novels (two of them national award winners) and three teenage novels, along with stories, essays, articles and reviews. His research investigates creative writing processes and the teaching of creative writing. He is the co-founding editor of TEXT: Journal of writing and writing courses, at http://www.textjournal.com.au

Keywords:

Creative writing - creative Nonfiction - experimental autobiography - automatic writing 
My sister, who is a naturopath, told me that the rate of growth of my fingernails depends on how busy I am. When I'm super-busy, they'll go gang-busters; when I relax, they'll take it easy. They are always going gang-busters.

Also, I've read that the rate at which the continents are moving together is the same as that by which our fingernails grow. One day the continents will meet up again: their progress away from each other, begun long ago, has given way to their progress towards each other in a new arrangement. It's happening in accordance with my fingernails.

Each time I cut my fingernails, the world has headed further to collision. I should take it easy.

When I get home from work there is only ever more work to do. Employment in a university is relentless. Student numbers increase and government funding decreases. I supervise almost a million dollars worth of postgraduate students, but I am told I can't have an undergraduate tutor, the numbers do not currently support my request. I recall that in 25 years of employment at my university, money has always been tight, except when I was head of school. Funny that. But perhaps I'm fantasizing. Perhaps colleagues have a different recollection. Perhaps I dealt with their requests in the same way mine are now dealt with.

When we were divorcing, my wife and I worked out an excellent method for dividing up the cookery books. We both loved cooking and we had amassed a significant collection. We had a tall bookshelf in the kitchen to house our library. Mediterranean, Mexican, Indian, Japanese - even American - the world of cooking was represented. How to cook a potato, an egg, a tomato or a squash, each had a special book. How to cook it Indonesian or Thai or Spanish-style was catered for. We both wanted the whole collection after divorce, so we came up with a formula. Each took turns to pick two books they considered were of equal value. The other then chose between the two. It was brilliant. It was probably my best experience of the entire divorce.

A female student accused me of sexual harassment. I reported it immediately to the University and found the HR department had an excellent set of processes in place. It took a while, but I was exonerated. The police were involved and a sergeant said to me: 'Yes, we really have a loopy here.' Later, when I had a colonoscopy, the surgeon told me: 'Ah, you're the guy who got that madwoman sorted out. I'm eternally grateful. She did the same to me and I couldn't say anything. I'd made a house-call to her place.'

When my father was dying, I visited him in a university hospital in Sydney. This was a far better place than the public hospital he had been in where the roof leaked and medical equipment cluttered the corridors so that it was hard to get past. He was basically without 
the means to express himself, just a man propped in a bed staring. When I walked in, his face lit up. It was the movement of a minimal number of facial muscles - all he had left to him - and it drove a knife into my heart. Dying is hell, I decided.

I abandoned my first family when my daughter was 5 years old. There's much to be said about this period in my life, and I've not said it. But I have thought about it for 35 years. My first wife and I did not speak to each other until our daughter's marriage day. Across the wedding feast table she said to me, 'We did a good job'. I agreed.

On Mykonos, my lover arrived and I had a feast prepared for her. As I remember, there were specially stuffed olives and particular tinned fish, tart local feta and red-as-hell tomatoes, exotic local biscuits plus a brilliant bottle of expensive Greek wine - yes, there is wonderful wine in Greece. I met her at the airport and we took the taxi to the hotel. We wolfed the feast and got serious. The bed broke, fell down at its bottom end, and we had to explain it to the hotel owner who thereafter kissed my lover as often as he could.

It occurs to me that writing about one's life is always dangerous. What kind of writer has safe things to say? As I am a writer employed by a university now rewarded for my creative work as research, what limits must I put on the recollections I admit to? What will get me into trouble? If I think I am seriously researching the creative nonfiction genre, for example, how far can I go? How long before the university says: 'This is genuine stuff related to a genuine creative writing research project, but be careful with it. There's a point at which research moves into the untenable, a point at which research is no longer research, it's narcissism, it's indulgence, it's litigious'.

I'm resisting coming back to any theme I might seem to be creating. I want to keep the flow going, only directed by the whim of the moment of writing. This is not quite what the Surrealists did with their concept of automatic writing, but it is related. I am editing the words I put down, but not the narrative structure. I'm letting the flow happen for itself. I'll come back later and do some editing, but with this piece I am keen to present it more or less exactly as it comes out.

And now, I am immediately breaking my own rule. Having written the beginning of the section following, I'm now inserting. I want to say something that is really important to me, but I'm not sure what it is. Many things are important to me. For some reason I suddenly have a vision in my mind of a car park near where my mother lives. Why am I thinking of this place? It is of no consequence to me whatsoever. I took a long walk once from my mother's unit and ended up in this car park. How come I can see it so clearly right now? 
Well, I can analyze it, I guess. This image welled up from within me because it represents a whole lot of stuff making traffic in my brain at a subconscious level. Wow! Clearly, my mother is important to me. Clearly, I think of myself exploring in a bitumen wasteland while on the way back home. Clearly, being out in the world, but also returning, is important to me.

My daughters, as kids, on separate occasions, ran away when my wife and I were fighting. I don't blame them. There are hells in the world and one would be silly not to run from them. I remember going after my daughters - out into the bush and in the suburbs - and trying to talk them round, trying to get them to come back home. I was successful on both occasions, and I don't know why. If I had been them, I would have stayed away.

One of the first public rebukes I had, that was not from my parents, was in the Boy Scout Cubs. As a ten year old I was biting my fingernails down as far as I could, to the point of painfulness. Why? I don't know. There must have been issues about self-image and my place in the world that I couldn't cope with. I can see now that biting back my fingernails had something to do with the continents heading for collision. I was trying to put off my understanding of how the world operated. I was biting the world back from going on.

I have found a moment to write this piece amongst all the other deadlines pending. I could tell the truth and say that I got so drunk today after writing an academic piece for publication, and actually finished it, that I found myself with time left over for writing something I really wanted to do. But I might not be believed. If creative nonfiction is about truth-telling while using the structures of fiction, then that is what I have set out to do here. I will claim that what I have written is innovative research, it uses fragmentary narrative structure in the context of CNF. I may be wrong, but I think this is the kind of thing the government's ERA requirements are talking about.

Checking the horizon from an isolated boat isn't like checking the sea horizon from land. From a tall headland with an uninterrupted view, the sea's horizon appears curved - we get a sense of the earth's roundness. But from an isolated boat, the horizon goes all the way round, and is straight. It tells us nothing about curvature. When boats move, they take their horizon-ring with them. On an island, being like a stationary boat, when you stand atop it and see a surrounding circle of sea, you can be forgiven for thinking you are standing at the centre of the world, and it's flat. Islands take the perspective of the subject, not the context. 


\section{Research statement}

\section{Research background}

In the 1990s, creative nonfiction was considered experimental. Rapidly, however, this new process of applying the conventions of fiction writing to autobiography, biography and long journalism was challenged (Loose 2001) and the idea of experimental autobiography has continued to have difficulty establishing itself.

\section{Research contribution}

This work sets out to tell absolute (and possibly awful) truths about myself via a process approximating automatic writing as defined by the Surrealists (Breton 1972: 22-3). The piece was written in a single sitting in 2013, with the RS added in 2015. It tries to write memoir without shaping it consciously: to see how my life might spill back out of me when I did not interfere too much with the spilling.

\section{Research significance}

This piece is part of a portfolio concerned with the boundaries (or lack thereof) between autobiography and fiction (see Krauth 2010, 2012). In line with Brien's examinations of speculative biography $(2002,2014)$, this piece tests the concept of memoirist narrative structure in its both creative and academic contexts.

\section{Works cited}

Breton, A 1972 [1924] 'Manifesto of Surrealism' Manifestoes of Surrealism trans R Seaver and HR Lane, Ann Arbor, MI: U of Michigan P, 1-47

Brien DL 2002 'Being honest about lying: defining the limits of auto/biographical writing' TEXT 6.1, at http://www.textjournal.com.au/april02/brien.htm (accessed 2 May 2015)

Brien, DL 2014 “"Welcome creative subversions": experiment and innovation in recent biographical writing' TEXT 17.1, at http://www.textjournal.com.au/april14/brien.htm (accessed 2 May 2015)

Krauth, N 2012 'Polonaise in F Sharp Minor, Opus 44, TEXT Special Issue 15 (accessed 21 October 2014)

Krauth, N 2010 'Majorca: unreal estate’, TEXT Special Issue 7 (accessed 21 October 2014)

Loose, J 2001 'Stranger than fiction' The Guardian Biography, 28 July, at http://www.theguardian.com/books/2001/jul/28/biography.highereducation (accessed 21 October 2014) 